\title{
Hemoglobin-Based Oxygen Carriers Incorporating Nanozymes for the Depletion of Reactive Oxygen Species
}

Jansman, Michelle Maria Theresia; Liu, Xiaoli; Kempen, Paul; Clergeaud, Gael; Andresen, Thomas Lars; Thulstrup, Peter Waaben; Hosta-Rigau, Leticia

\author{
Published in: \\ ACS Applied Materials and Interfaces
}

Link to article, DOI:

10.1021/acsami.0c14822

Publication date:

2020

Document Version

Peer reviewed version

Link back to DTU Orbit

Citation $(A P A)$ :

Jansman, M. M. T., Liu, X., Kempen, P., Clergeaud, G., Andresen, T. L., Thulstrup, P. W., \& Hosta-Rigau, L. (2020). Hemoglobin-Based Oxygen Carriers Incorporating Nanozymes for the Depletion of Reactive Oxygen Species. ACS Applied Materials and Interfaces, 12(45), 50275-50286. https://doi.org/10.1021/acsami.0c14822

\section{General rights}

Copyright and moral rights for the publications made accessible in the public portal are retained by the authors and/or other copyright owners and it is a condition of accessing publications that users recognise and abide by the legal requirements associated with these rights.

- Users may download and print one copy of any publication from the public portal for the purpose of private study or research.

- You may not further distribute the material or use it for any profit-making activity or commercial gain

- You may freely distribute the URL identifying the publication in the public portal 


\title{
Hemoglobin-based Oxygen Carriers Incorporating Nanozymes for the Depletion of Reactive Oxygen Species.
}

Michelle Maria Theresia Jansman, ${ }^{a}$ Xiaoli Liu, ${ }^{a}$ Paul Kempen, ${ }^{a}$ Gael Clergeaud, ${ }^{a}$ Thomas Lars Andresen, ${ }^{a}$ Peter Waaben Thulstrup ${ }^{b}$ and Leticia Hosta-Rigau ${ }^{*}, a$

${ }^{a}$ Department of Health Technology, Center for Nanomedicine and Theranostics, Technical University of Denmark, Nils Koppels Allé, Building 423, 2800 Kgs. Lyngby, Denmark.

${ }^{\mathrm{b}}$ Department of Chemistry, University of Copenhagen, Universitetsparken 5, 2100 Copenhagen, Denmark.

*E-mail: leri@dtu.dk

KEYWORDS

Antioxidant activity; Blood substitutes; Cerium oxide nanoparticles; Hemoglobin; Layer-by-layer assembly; Nanozymes.

\begin{abstract}
While transfusion of donor blood is a reasonably safe and well-established procedure, artificial oxygen carriers offer several advantages over blood transfusions. These benefits include compatibility with all blood types thus avoiding the need for cross matching, availability, lack of infection and long-term storage. Hemoglobin ( $\mathrm{Hb}$ )-based oxygen carriers (HBOCs) are being explored as an "oxygen bridge" to replace or complement standard blood transfusions in extreme, life-threatening situations such as trauma in remote locations or austere battlefield or when blood is not an option due to compatibility issues or patient refusal due to religious objections.
\end{abstract}


Herein, a novel HBOC was prepared using the layer-by-layer technique. A poly(lactide-coglycolide) core was fabricated and subsequently decorated with $\mathrm{Hb}$ and nanozymes. The $\mathrm{Hb}$ was coated with poly(dopamine) and preservation of the protein structure and functionality was demonstrated. Next, cerium oxide nanoparticles were incorporated as nanozymes and their ability to deplete reactive oxygen species (ROS) was shown. Finally, decorating the nanocarriers surface with poly(ethylene glycol) decreased protein adsorption and cell association/uptake. The asprepared Hb-based oxygen nanocarriers were shown to be hemo- and biocompatible. Their catalytic potential was furthermore demonstrated in terms of superoxide radical- and peroxidescavenging abilities, which were retained over multiple cycles. Overall, these results demonstrate that the reported nanocarriers show potential as novel oxygen delivery systems with prolonged catalytic activity against ROS.

\section{INTRODUCTION}

The transfusion of donor blood is a well-established and indispensable clinical procedure. Whole blood or isolated red blood cells (RBCs) are routinely employed to replenish blood loss during surgery and traumatic injury, and to treat diseases such as chronic anemia, hemophilia, and ischemia. ${ }^{1-3}$ Unfortunately, blood transfusions come with limitations due to the need of typing and cross-matching, short storage life-time, limited supply, and the possible risks of viral and bacterial transmission. ${ }^{4,5}$ Therefore, research efforts have focused in developing RBC substitutes that circumvent the aforementioned drawbacks.

Hemoglobin ( $\mathrm{Hb}$ )-based oxygen carriers (HBOCs) are one of the most prominent types of RBC substitutes being investigated, and they make use of the excellent oxygen $\left(\mathrm{O}_{2}\right)$-carrying and delivering properties of native $\mathrm{Hb} .{ }^{1,6}$ In $\mathrm{HBOCs}, \mathrm{Hb}$ is chemically modified or encapsulated to overcome the adverse effects of intravascular cell-free $\mathrm{Hb}$, which include renal toxicity, inflammation, and vasoconstriction. ${ }^{1,47}$ Multiple chemically-modified HBOCs underwent clinical development, but showed persistent safety concerns with increased risk of myocardial infarction and mortality. ${ }^{8,9}$ This toxicity was mainly attributed to the extravasation of the HBOCs. Because of their small size, the developed HBOCs could infiltrate in between the endothelial cells lining the capillary walls into the smooth muscle tissue. There, the HBOCs acted as nitric oxide (NO) scavengers. Being NO a potent vasodilator, its scavenging resulted in cardiovascular 
complications. Therefore, $\mathrm{Hb}$ encapsulation strategies have gained attraction, shielding $\mathrm{Hb}$ from permeating through the blood vessels, while simultaneously providing a protective environment against tetramer dissociation and loss of function. Examples of encapsulation platforms developed so far include liposomes, ${ }^{10}$ polymeric nanoparticles, ${ }^{11}$ hydrogels, ${ }^{12}$ and metal-organic frameworks (MOFs) ${ }^{13}$ However, despite the advancements in recent years, fabrication of HBOCs that are nontoxic, hemocompatible, biodegradable, with good $\mathrm{O}_{2}$ delivery properties, and are long-circulating in the bloodstream still remains a challenge.

In biological $\mathrm{RBCs}, \mathrm{Hb}$ 's $\mathrm{O}_{2}$-delivery capacity is secured by an antioxidant system that involves both non-enzymatic (e.g., glutathione, ascorbic acid) and enzymatic (e.g., superoxide dismutase (SOD), catalase (CAT), and glutathione peroxidase) entities. ${ }^{14}$ This antioxidant system protects $\mathrm{Hb}$ from exogenous and endogenous reactive oxygen species (ROS). RBCs take up exogenous ROS when circulating in the microvasculature, since ROS are produced by the cellular components of the vascular wall. ${ }^{15}$ Additionally, endogenous ROS are produced within the RBCs following $\mathrm{Hb}$ 's autoxidation into methemoglobin (metHb). ${ }^{14,16}$ MetHb conversion, apart from resulting in the loss of $\mathrm{Hb}^{\prime} \mathrm{O}_{2}$-carrying ability, also leads to the production of the superoxide radical anion $\left(\mathrm{O}_{2}{ }^{-}\right)$. Within RBCs, metHb is reduced back to active $\mathrm{Hb}$ by cytochrome $\mathrm{b} 5$ reductase, while the formation of ROS is prevented. SOD catalyzes the dismutation of $\mathrm{O}_{2}{ }^{-}$into hydrogen peroxide $\left(\mathrm{H}_{2} \mathrm{O}_{2}\right) .{ }^{16} \mathrm{Next}, \mathrm{H}_{2} \mathrm{O}_{2}$ can be reduced by CAT into $\mathrm{O}_{2}$ and water. However, in the absence of such an antioxidant system, $\mathrm{H}_{2} \mathrm{O}_{2}$ reacts with both metHb and oxygenated- $\mathrm{Hb}$ (oxy-Hb), initiating heme-mediated oxidative reactions. ${ }^{14,16}$

Approaches to develop $\mathrm{HBOCs}$ where $\mathrm{Hb}$ is protected against oxidation, thus preserving its $\mathrm{O}_{2}$ delivery properties, include the incorporation of CAT and SOD. ${ }^{17,18}$ Chang et al. pioneered this approach by co-polymerizing $\mathrm{Hb}$ together with $\mathrm{CAT}$ and SOD. The resulting polyHb-CAT-SOD complex was able to remove ROS while also decreasing metHb conversion and heme release. ${ }^{19,20}$ Despite these encouraging results, employing enzymes has several limitations which include high production costs, short catalytic half-lives, limited active sites, and environmental sensitivity. ${ }^{21,22}$ Therefore, herein, the novel approach of incorporating nanozymes is explored. Nanozymes are a type of nanoparticulate systems displaying enzyme-like properties, which overcome the aforementioned limitations. ${ }^{23}$ Furthermore, since nanozymes are synthetic compounds, additional advantages include decreased batch-to-batch variations and lack of xenogeneic contamination. 
While nanozymes offer enormous potential, a solitary example has considered them in the context of HBOCs. Hosaka et al. incorporated platinum nanoparticles (NPs) in their HBOC system, demonstrating high $\mathrm{H}_{2} \mathrm{O}_{2}$ and $\mathrm{O}_{2}{ }^{--}$scavenging properties. ${ }^{24}$ However, despite the promising results, no further studies were conducted in this direction.

From a different perspective, achieving long circulation times is a paramount requisite for the clinical translation of HBOCs. Upon intravenous administration, foreign materials are removed by the mononuclear phagocyte system (MPS). ${ }^{25}$ To reduce recognition by the MPS, the adsorption of opsonins onto the NPs' surface has to be reduced or eliminated. The golden standard is decorating the surface with poly(ethylene glycol) (PEG), which creates steric hindrance and blocks proteinbinding sites to reduce opsonisation and subsequent phagocytosis. $^{26}$

Thus, in this report, a novel HBOCs with antioxidant and stealth properties is presented (Schematic 1). In particular, the layer-by-layer (LbL) technique was employed to adsorb the different functional components onto a poly(lactide-co-glycolide) (PLGA) core. Since PLGA is a biodegradable, biocompatible, and FDA approved polymer, PLGA-NPs are being widely explored as colloidal carrier systems. Cerium oxide $\left(\mathrm{CeO}_{2}\right)-\mathrm{NPs}$, which are a new class of nanozymes with excellent ROS-scavenging activity, were selected as the antioxidant component. The assembly was finally capped with a poly(L-Lysine)-graft-PEG (PLL-g-PEG) co-polymer to obtain a low-fouling effect. The $\mathrm{O}_{2}$ carrying potential, catalytic activity, and the stealth-like properties of this new HBOC, as well as the overall biocompatibility in terms of hemolytic rate and cell viability, were evaluated. By characterizing the multifaceted properties of the system, we hope to demonstrate the potential of these novel HBOCs.

\section{MATERIALS AND METHODS}

\subsection{Materials.}

Tris(hydroxymethyl)aminomethane (TRIS), phosphate buffer saline (PBS), tert-butanol, dopamine (DA), Amicon Ultra-15 Centrifugal Filter Unit (10 kDa MWCO), cerium(III) nitrate hexahydrate $\left(\mathrm{Ce}\left(\mathrm{NO}_{3}\right)_{3} \bullet 6 \mathrm{H}_{2} \mathrm{O}\right)$, citric acid, hydrochloric acid $(\mathrm{HCl})$, nitric acid $\left(\mathrm{HNO}_{3}\right)$, ammonia ( $25 \%$ solution), hydrogen peroxide $\left(\mathrm{H}_{2} \mathrm{O}_{2}\right)$, horseradish peroxidase (HRP), CAT from bovine liver, SOD from bovine erythrocytes, cell proliferation reagent WST-1, ethylenediaminetetraacetic 
acid solution (EDTA), xanthine, xanthine oxidase (XO) from bovine milk, potassium dioxide $\left(\mathrm{KO}_{2}\right)$, Poly $\left(L\right.$-lysine) (PLL, $\mathrm{M}_{\mathrm{W}}$ 30-70 kDa), fluorescein isothiocyanate (FITC)-labelled immunoglobulin $\mathrm{G}\left(\mathrm{IgG}^{\mathrm{F}}\right)$ from human serum, Dulbecco's Modified Eagle's Medium-high glucose (DMEM D5796), penicillin/streptomycin, fetal bovine serum (FBS), trypsin, and the human umbilical vein endothelial cell line (HUVEC) were purchased from Merck Life Science A/S (Søborg, DK). Amplex ${ }^{\mathrm{TM}}$ Red reagent and PrestoBlue cell viability reagent were purchased from ThermoFisher Scientific (Waltham, MA, USA). Bovine blood with citrate (Product no. 77667) was purchased from SSI Diagnostica A/S (Hillerød, DK). Hb was obtained by extraction from the bovine blood (see ESI). Endothelial Cell Medium (ECM) Kit supplemented with 5\% FBS, $1 \%$ penicillin/streptomycin solution, and 1\% endothelial cell growth supplement was purchased from Innoprot (Derio-Biskaia, ESP). The RAW 264.7 mouse macrophage cell line was purchased from European Collection of Authenticated Culture Collections (ECACC, Wiltshire, UK).

PLGA-NPs, FITC-labelled bovine serum albumin (BSA) $\left(\mathrm{BSA}^{\mathrm{F}}\right)$ and PLL-g-PEG were synthesized (see ESI).

TRIS 1 contains $10 \mathrm{mM}$ TRIS (pH 8.5); TRIS 2 contains $10 \mathrm{mM}$ TRIS and $150 \mathrm{mM} \mathrm{NaCl}(\mathrm{pH}$ 7.4). All buffers were made with ultrapure water (Milli-Q (MQ), gradient A 10 system, TOC $<4$ ppb, resistance $18 \mathrm{MV} \mathrm{cm}$, EMD Millipore, USA).

\subsection{Cell Culture.}

RAW 264.7 cells were cultured in DMEM supplemented with FBS (10\% v/v) and penicillin/streptomycin ( $1 \% \mathrm{v} / \mathrm{v}, 10000 \mathrm{U} \mathrm{mL}^{-1}$ and $10 \mu \mathrm{g} \mathrm{mL}^{-1}$, respectively). HUVECs were cultured in ECM supplemented with FBS (5\% v/v), penicillin/streptomycin (1\% v/v, $10000 \mathrm{U}$

$\mathrm{mL}^{-1}$ and $10 \mu \mathrm{gL}^{-1}$, respectively), and endothelial cell growth supplements $(1 \% \mathrm{v} / \mathrm{v})$. Both cell lines were cultured at $37{ }^{\circ} \mathrm{C}$ in a humidified incubator with $5 \% \mathrm{CO}_{2}$.

\subsection{Fabrication and Characterization of Polydopamine (PDA)-Coated $\mathrm{Hb}\left(\mathrm{Hb}^{\mathrm{PDA}}\right)$.}

The coating of $\mathrm{Hb}$ with PDA was based on the oxidative polymerization of DA in TRIS $1 .{ }^{27}$ Briefly, solutions of $\mathrm{Hb}\left(8 \mathrm{mg} \mathrm{mL}^{-1}\right)$ and DA $\left(1.6 \mathrm{mg} \mathrm{mL}^{-1}\right)$ in TRIS 1 were mixed at a 1:1 volume ratio and transferred to a tube rotator for $3 \mathrm{~h}$. The resulting $\mathrm{Hb}^{\mathrm{PDA}}$ was washed in TRIS $2(3 \times, 9700$ 
g, 5 min) using a bench-top centrifuge (MiniSpin, Eppendorf AG, Hamburg, DE) and Amicon centrifugal filters.

The hydrodynamic size of $\mathrm{Hb}^{\mathrm{PDA}}$ was evaluated by dynamic light scattering (DLS) (Zetasizer nanoseries nano-ZS, Malvern Panalytical Ltd, Malvern, UK). To determine the secondary structure, Fourier-transform infrared spectroscopy (FTIR) analysis was conducted using a spectrometer Spectrum 100 (Perkin Elmer Inc., Wellesley, MA, USA). Circular dichroism (CD) spectra were obtained using a Jasco J-815 spectropolarimeter (JASCO, Essex, UK). To assess the $\mathrm{Hb}$ 's functionality, a gas binding and release study was conducted using a UV-2600 UV-Vis Spectrophotometer (Shimadzu Corp., Kyoto, JP). The oxygen dissociation curves (ODC) were obtained using a Hemox analyzer (TSC Scientific Corp., New Hope, PA, USA).

\subsection{Fabrication and Characterization of $\mathrm{CeO}_{2}-\mathrm{NPs}$.}

2.4.1. Fabrication and characterization of $\mathbf{C e O}_{2}-\mathrm{NPs}$. Citrate-capped $\mathrm{CeO}_{2}-\mathrm{NPs}$ were synthesized following a reported protocol. ${ }^{28}$ Specifically, citric acid (120 mg) was added to a $\mathrm{Ce}\left(\mathrm{NO}_{3}\right)_{3} \cdot 6 \mathrm{H}_{2} \mathrm{O}$ solution $\left(12.5 \mathrm{~mL}, 21.71 \mathrm{mg} \mathrm{mL}^{-1}\right.$ in $\left.\mathrm{MQ}\right)$ followed by gentle mixing, poured rapidly into an ammonia solution $(50 \mathrm{~mL}, 3 \mathrm{M})$ and stirred for $2 \mathrm{~h}$. The obtained $\mathrm{CeO}_{2}-\mathrm{NPs}_{\text {were }}$ purified by adding $\mathrm{HCl}(\sim 25 \mathrm{~mL}, 5 \mathrm{M})$ until precipitation occurred. The $\mathrm{CeO}_{2}-\mathrm{NPs}$ were allowed to sediment, the supernatant was then removed, and the $\mathrm{CeO}_{2}-\mathrm{NPs}$ were re-suspended in MQ. These washing steps were repeated three times. After the final wash, the supernatant was removed and the $\mathrm{pH}$ of the $\mathrm{CeO}_{2}$-NPs suspension was adjusted to neutral $\mathrm{pH}$ using an ammonia solution (1 M). All glassware was treated with Aqua Regia $\left(\mathrm{HNO}_{3}: \mathrm{HCl}, 1: 3\right.$ molar ratio) before usage.

The cerium content of the $\mathrm{CeO}_{2}-\mathrm{NPs}$ suspension was determined by inductively coupled plasma mass spectrometry (ICP-MS) (iCAPQ, ThermoFisher Scientific, Waltham, USA). The content was also characterized by UV-Vis spectroscopy (NanoDrop 2000c, ThermoFisher Scientific, Waltham,

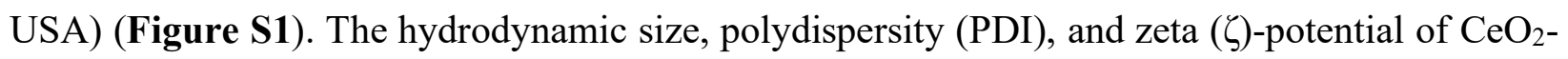
NPs were evaluated using the Zetasizer. The size, morphology, and selected area diffraction (SAD) patters of the $\mathrm{CeO}_{2}-\mathrm{NPs}$ were evaluated using a Tecnai T20 G2 transmission electron microscope (TEM) (Thermo Fisher Scientific, Waltham, MA, USA). 
2.4.2. Catalytic Activity of $\mathrm{CeO}_{2}$-NPs. To determine the SOD-like activity $\left(\mathrm{O}_{2}{ }^{-}\right.$scavenging), the WST-1 assay was employed. XO $\left(10 \mu \mathrm{L}, 0.05 \mathrm{U} \mathrm{mL}^{-1}\right)$ was added to $200 \mu \mathrm{L}$ of reagent mixture containing WST-1 $(2.5 \% \mathrm{v} / \mathrm{v})$, EDTA $(0.1 \mathrm{mM})$, and xanthine $(0.1 \mathrm{mM})$, mixed with $\mathrm{CeO}_{2}-\mathrm{NPs}$ $(100 \mu \mathrm{L}, 0-2 \mathrm{mM})$ or SOD $\left(100 \mu \mathrm{L}, 0-1000 \mathrm{U} \mathrm{mL}^{-1}\right)$, all in TRIS 2 . The mixture was incubated for 15 min using a thermoshaker (PHMT Thermoshaker, Grant-bio, UK) at $37^{\circ} \mathrm{C}$ with a shaking speed of $1400 \mathrm{rpm}$. Next, $180 \mu \mathrm{L}$ of the suspension were transferred to a 96 -well plate and the absorbance (Abs) at $438 \mathrm{~nm}$ was measured using a multimode plate reader (Tecan Spark, Tecan Group Ltd., Männedorf, CH). TRIS $2(100 \mu \mathrm{L})$ with $200 \mu \mathrm{L}$ of reagent mixture, with and without $\mathrm{XO}\left(10 \mu \mathrm{L}, 0.05 \mathrm{U} \mathrm{mL}^{-1}\right)$ were used as positive and negative controls, respectively, to calculate the normalized Abs (nAbs).

The CAT-like activity $\left(\mathrm{H}_{2} \mathrm{O}_{2}\right.$ scavenging $)$ was assessed using the Amplex Red assay. $\mathrm{H}_{2} \mathrm{O}_{2}(10 \mu \mathrm{L}$, $0.09 \mathrm{mM})$ was added to $\mathrm{CeO}_{2}$-NPs $(100 \mu \mathrm{L}, 0-5 \mathrm{mM})$ or CAT $\left(100 \mu \mathrm{L}, 0-14000 \mathrm{U} \mathrm{L}^{-1}\right)$, all in TRIS 2, and incubated for $15 \mathrm{~min}$ in the thermoshaker. HRP $\left(100 \mu \mathrm{L}, 2 \mathrm{U} \mathrm{mL}^{-1}\right)$ and Amplex Red $(10 \mu \mathrm{L}, 0.1 \mathrm{mM})$ were added to the suspension, followed by $5 \mathrm{~min}$ incubation in the thermoshaker. $180 \mu \mathrm{L}$ of the suspension were transferred to a 96-well plate and the fluorescence intensity (FI) of the resorufin product was measured using the plate reader ( $\lambda \mathrm{ex} / \lambda \mathrm{em}$ : 530/586 nm). TRIS 2 (100 $\mu \mathrm{L})$ incubated with and without $\mathrm{H}_{2} \mathrm{O}_{2}(10 \mu \mathrm{L}, 0.09 \mathrm{mM})$ were used as positive and negative controls, respectively, to calculate the normalized FI (nFI).

\subsection{Fabrication and Characterization of the Hb-loaded Nanocarriers (NCs).}

The LbL technique was used for the assembly of the Hb-loaded NCs. PLGA-NPs $(1000 \mu \mathrm{g})$ were incubated in DA solutions ( $300 \mu \mathrm{L}, 0.5 \mathrm{mg} \mathrm{mL}^{-1}$ in TRIS 1) for $30 \mathrm{~min}$. The PDA-coated PLGANPs were washed in TRIS $2(2 \times, 4847 \mathrm{~g}, 4 \mathrm{~min})$. Next, the following layers in TRIS 1 were deposited for $10 \mathrm{~min}$ : PLL $\left(300 \mu \mathrm{L}, 1.0 \mathrm{mg} \mathrm{mL}^{-1}\right), \mathrm{Hb}^{\mathrm{PDA}}\left(300 \mu \mathrm{L}, 2.0 \mathrm{mg} \mathrm{mL}^{-1}\right)$, PLL $(300 \mu \mathrm{L}$, $\left.1.0 \mathrm{mg} \mathrm{mL}^{-1}\right), \mathrm{CeO}_{2}$-NPs $\left(300 \mu \mathrm{L}, 3.75 \mathrm{mM}\right.$ ), and PLL-g-PEG solutions ( $300 \mu \mathrm{L}, 1.5 \mathrm{mg} \mathrm{mL}^{-1}$ ). After each deposition step, at least 2 washes were conducted. The concentrations were determined by $\zeta$-potential saturation curves (Figure S2).

The hydrodynamic size, PDI, and $\zeta$-potentials were measured using the Zetasizer. Encapsulation content was determined by the Nanodrop and ICP-MS. CryoTEM imaging was performed using a FEI Tecnai G2 20 TWIN TEM. The final PLGA/Hb ${ }^{\mathrm{PDA}} /\left(\mathrm{CeO}_{2}-\mathrm{NPs}\right) / \mathrm{PEG}-\mathrm{NCs}$ were visualized by 
differential interference contrast (DIC) microscopy (Olympus Inverted IX83 microscope equipped with a $60 \times$ oil-immersion objective).

\subsection{Evaluation of the Stealth Coating.}

2.6.1. Protein Adsorption Study. The PEGylation effect of PLGA/Hb ${ }^{\mathrm{PDA}} /\left(\mathrm{CeO}_{2}-\mathrm{NPs}\right) / \mathrm{PEG}-\mathrm{NCs}$ was assessed by a protein adsorption. $\mathrm{BSA}^{\mathrm{F}}\left(100 \mu \mathrm{L}, 1.0 \mathrm{mg} \mathrm{mL}^{-1}\right)$ or $\operatorname{IgG}^{\mathrm{F}}\left(100 \mu \mathrm{L}, 1.0 \mathrm{mg} \mathrm{mL}^{-}\right.$ $\left.{ }^{1}\right)$ in TRIS 2 was added to a suspension of either PLGA/Hb ${ }^{\mathrm{PDA}} /\left(\mathrm{CeO}_{2}-\mathrm{NPs}\right)-\mathrm{NCs}$ or $\mathrm{PLGA} / \mathrm{Hb}^{\mathrm{PDA}} /\left(\mathrm{CeO}_{2}\right.$-NPs $) / \mathrm{PEG}-\mathrm{NCs}\left(100 \mu \mathrm{L}, \sim 2.7 \times 10^{6} \mathrm{NCs}\right.$ in TRIS 2$)$ and incubated for $4 \mathrm{~h}$ in the thermoshaker. Next, the samples were washed in TRIS $2(2 \times, 6705 \mathrm{~g}, 4 \mathrm{~min})$ to remove unbound proteins. The FI of the nanocarriers resulting from the adsorbed $\mathrm{BSA}^{\mathrm{F}}$ and $\operatorname{IgG}^{\mathrm{F}}$ onto the NCs surface was evaluated by a BD Accuri C6 flow cytometer (BD Biosciences, Sparks, MD, USA).

2.6.2. Cell Association Study. In a 96-well plate, 30000 RAW 464.7 or 15000 HUVEC cells per well were seeded and allowed to attach for $24 \mathrm{~h}$. The cells were then washed in PBS $(2 \times, 200 \mu \mathrm{L})$ and incubated with different amounts of $\mathrm{PLGA}^{\mathrm{F}} / \mathrm{Hb}^{\mathrm{PDA}} /\left(\mathrm{CeO}_{2}-\mathrm{NPs}\right)-\mathrm{NCs}$ or $\mathrm{PLGA}^{\mathrm{F}} / \mathrm{Hb}^{\mathrm{PDA}} /\left(\mathrm{CeO}_{2}-\mathrm{NPs}\right) / \mathrm{PEG}-\mathrm{NCs}\left(200 \mu \mathrm{L}, 0-7.5 \times 10^{6} \mathrm{NCs} \mathrm{mL}^{-1}\right.$ in cell media) for $4 \mathrm{~h}$. After incubation, the cells were washed in PBS $(3 \times, 200 \mu \mathrm{L})$ and detached from the wells using trypsin $\left(60 \mu \mathrm{L}, 0.5 \mathrm{mg} \mathrm{mL}^{-1}\right)$. The cell suspensions were collected by adding FBS-free media $(200 \mu \mathrm{L}$ per well) and the cell association/uptake was evaluated by flow cytometry. The cell mean fluorescence intensity (CMFI) and cellular uptake efficiency (CUE) were assessed. Cells without exposure to the NCs were used as controls. The CUE was determined as the percentage of cells with a CMFI higher than the autofluorescence level of the cells. The CMFI was normalized (nCMFI) to $\mathrm{PLGA}^{\mathrm{F}} / \mathrm{Hb}^{\mathrm{PDA}} /\left(\mathrm{CeO}_{2}-\mathrm{NPs}\right)-\mathrm{NCs}$ at $7.5 \times 10^{6} \mathrm{NCs} \mathrm{mL}^{-1}$.

\subsection{Biocompatibility.}

2.7.1. Cell Viability. In a 96-well plate, 30000 RAW 464.7 or 15000 HUVEC cells per well were seeded and allowed to attach for $24 \mathrm{~h}$. Next, the cells were washed in PBS $(2 \times, 200 \mu \mathrm{L})$ and incubated with different amounts of PLGA ${ }^{\mathrm{F}} / \mathrm{Hb}^{\mathrm{PDA}} /\left(\mathrm{CeO}_{2}-\mathrm{NPs}\right) / \mathrm{PEG}-\mathrm{NCs}\left(200 \mu \mathrm{L}, 0-3.0 \times 10^{7}\right.$ $\mathrm{NCs} \mathrm{mL}^{-1}$ in cell media). After $4 \mathrm{~h}$ incubation, the cells were washed in PBS $(3 \times, 200 \mu \mathrm{L})$ and PrestoBlue $(100 \mu \mathrm{L}, 10 \% \mathrm{v} / \mathrm{v}$ in cell media) was added. The cells were incubated for $1 \mathrm{~h}$ and then 
the supernatants were transferred to a $96-$ well plate to measure the resazurin product $(\lambda \mathrm{ex} / \lambda \mathrm{em}$ : $535 / 615 \mathrm{~nm}$ ). Cells only were used as the positive control, and media only was used as the negative control to calculate the normalized cell viability (nCV).

2.7.2. Hemocompatibility. The hemocompatibility of both $\mathrm{PLGA} / \mathrm{Hb}^{\mathrm{PDA}} /\left(\mathrm{CeO}_{2}-\mathrm{NPs}\right)-\mathrm{NCs}$ and $\mathrm{PLGA} / \mathrm{Hb}^{\mathrm{PDA}} /\left(\mathrm{CeO}_{2}\right.$-NPs $) / \mathrm{PEG}-\mathrm{NCs}$ was investigated by a haemolysis rate test. Whole blood from healthy donors was collected in heparin-coated tubes and washed in PBS $(3 \times, 1000 \mathrm{~g}, 15$ min, $\left.4^{\circ} \mathrm{C}\right)$. The cell-containing pellet was re-suspended in PBS $(50 \mathrm{~mL})$, and $200 \mu \mathrm{L}$ of this diluted blood cell suspension at $37^{\circ} \mathrm{C}$ was added to the NCs suspensions $\left(300 \mu \mathrm{L}, 0-1.2 \times 10^{7} \mathrm{NCs}\right.$ in PBS). The mixtures were incubated for $2 \mathrm{~h}$ in the thermoshaker (with gentle shaking). As negative and positive controls, the diluted blood cell suspension $(200 \mu \mathrm{L})$ was incubated in PBS or MQ water $(300 \mu \mathrm{L})$, respectively. Next, the samples were spun down $(1000 \mathrm{~g}, 10 \mathrm{~min})$ and the supernatants were collected followed by an additional centrifugation step (13000 g, $10 \mathrm{~min})$. The new supernatants were transferred to a 96-well plate and the Abs at $540 \mathrm{~nm}$ was recorded. The haemolysis rate was calculated as: haemolysis rate $(\%)=($ experimental value - negative control $) /($ positive control - negative control $) \times 100$. In parallel, the remaining cell-containing pellet after the first centrifugation step was collected and re-suspended in PBS. The morphology of the blood cells was assessed using the DIC microscope.

\subsection{Catalytic Activity.}

2.8.1. SOD-like activity. The influence of each functional layer of the Hb-loaded NCs on the decomposition of $\mathrm{O}_{2}{ }^{-}$was assessed using the WST-1 assay. Specifically, PLGA ${ }^{\mathrm{F}}-\mathrm{NPs}$, PLGA $^{\mathrm{F}} / \mathrm{PDA}-\mathrm{NCs}, \quad \mathrm{PLGA}^{\mathrm{F}} / \mathrm{Hb}^{\mathrm{PDA}}-\mathrm{NCs}, \quad \mathrm{PLGA}^{\mathrm{F}} / \mathrm{Hb}^{\mathrm{PDA}} /\left(\mathrm{CeO}_{2}-\mathrm{NPs}\right)-\mathrm{NCs} \quad$ and $\mathrm{PLGA}^{\mathrm{F}} / \mathrm{Hb}^{\mathrm{PDA}} /\left(\mathrm{CeO}_{2}-\mathrm{NPs}\right) / \mathrm{PEG}-\mathrm{NCs}$ were investigated. $\mathrm{XO}\left(10 \mu \mathrm{L}, 0.05 \mathrm{U} \mathrm{mL}^{-1}\right)$ was added to $200 \mu \mathrm{L}$ of reagent mixture containing WST-1 $(2.5 \% \mathrm{v} / \mathrm{v})$, EDTA $(0.1 \mathrm{mM})$, and xanthine $(0.1$ $\mathrm{mM})$, mixed with a NC suspension $\left(200 \mu \mathrm{L}, 1.5 \times 10^{6} \mathrm{NCs}\right)$, all in TRIS 2 . The suspensions were incubated for 15, 30, and 60 min using the thermoshaker, after which the NCs were spun down (6705 $\mathrm{g}, 4 \mathrm{~min}$ ), $180 \mu \mathrm{L}$ of the supernatant was transferred to a 96-well plate, and the Abs at 438 $\mathrm{nm}$ was measured. TRIS $2(100 \mu \mathrm{L})$ mixed with $200 \mu \mathrm{L}$ of reagent mixture, with and without XO $\left(10 \mu \mathrm{L}, 0.05 \mathrm{U} \mathrm{mL}^{-1}\right.$ ) were used as positive and negative controls, respectively, to calculate the nAbs. 
2.8.2. Combined SOD- and CAT-like activity. The ability of the Hb-loaded NCs to catalyze the reduction of $\mathrm{O}_{2}{ }^{-}$into $\mathrm{O}_{2}$ and $\mathrm{H}_{2} \mathrm{O}_{2}$, followed by the subsequent decomposition of $\mathrm{H}_{2} \mathrm{O}_{2}$ into $\mathrm{O}_{2}$ and $\mathrm{H}_{2} \mathrm{O}$, was assessed by the Amplex Red assay. ${ }^{27}$ Specifically, PLGA ${ }^{\mathrm{F}}$-NPs, PLGA ${ }^{\mathrm{F}} / \mathrm{PDA}-\mathrm{NCs}$, $\mathrm{PLGA}^{\mathrm{F}} / \mathrm{Hb}^{\mathrm{PDA}}-\mathrm{NCs}$, $\mathrm{PLGA}^{\mathrm{F}} / \mathrm{Hb}^{\mathrm{PDA}} /\left(\mathrm{CeO}_{2}-\mathrm{NPs}\right)-\mathrm{NCs}$, and $\mathrm{PLGA}^{\mathrm{F}} / \mathrm{Hb}^{\mathrm{PDA}} /\left(\mathrm{CeO}_{2}-\mathrm{NPs}\right) / \mathrm{PEG}-\mathrm{NCs}$ were investigated. $\mathrm{KO}_{2}(10 \mu \mathrm{L}, 0.14 \mathrm{mM}$ in TRIS 2) was added to the NCs suspensions (200 $\mu \mathrm{L}$, $1.5 \times 10^{6} \mathrm{NCs}$ in TRIS 2) and incubated for 15,30 , and $60 \mathrm{~min}$ in the thermoshaker. Next, the NCs were spun down (6705 g, $4 \mathrm{~min})$ and $180 \mu \mathrm{L}$ supernatant was collected and incubated with a solution of HRP ( $100 \mu \mathrm{L}, 2 \mathrm{U} \mathrm{mL}^{-1}$ in TRIS 2$)$ and Amplex Red (10 $\mu \mathrm{L}, 0.1 \mathrm{mM}$ in TRIS 2$)$ for 5 min. Finally, $180 \mu \mathrm{L}$ of the suspension was transferred to a $96-w e l l$ plate and the FI ( $\lambda$ ex/ $/ \lambda \mathrm{em}$ : $530 / 586 \mathrm{~nm})$ was measured. TRIS $2(200 \mu \mathrm{L})$ incubated with and without $\mathrm{KO}_{2}(10 \mu \mathrm{L})$ were used as positive and negative controls, respectively, to calculate the nFI.

2.8.3. Multiple Cycles of SOD- and CAT-like Activity. The $\mathrm{PLGA}^{\mathrm{F}} / \mathrm{Hb}^{\mathrm{PDA}} /\left(\mathrm{CeO}_{2}-\mathrm{NPs}\right) / \mathrm{PEG}-$ NCs $\left(200 \mu \mathrm{L}, 1.5 \times 10^{6} \mathrm{NCs}\right.$ in TRIS 2) were allowed to interact with $\mathrm{KO}_{2}(10 \mu \mathrm{L}, 0.14 \mathrm{mM})$ for 15 min using the thermoshaker after which the supernatant was collected and incubated with a solution of HRP $\left(100 \mu \mathrm{L}, 2 \mathrm{U} \mathrm{mL}^{-1}\right)$ and Amplex Red $(10 \mu \mathrm{L}, 0.1 \mathrm{mM})$ for $5 \mathrm{~min}$ in the thermoshaker. Finally, $180 \mu \mathrm{L}$ of the suspension was transferred to a 96 -well plate and the FI ( $\lambda$ ex/ $/ \lambda$ em: $530 / 586 \mathrm{~nm}$ ) was measured. Next, the $\mathrm{PLGA}^{\mathrm{F}} / \mathrm{Hb}^{\mathrm{PDA}} /\left(\mathrm{CeO}_{2}-\mathrm{NPs}\right) / \mathrm{PEG}-\mathrm{NCs}$ were resuspended in fresh TRIS $2(200 \mu \mathrm{L})$ and incubated again in a $\mathrm{KO}_{2}$ solution $(10 \mu \mathrm{L}, 0.14 \mathrm{mM})$ to conduct the second cycle of the cascade activity. The aforementioned process was repeated for five subsequent cycles. The cascade activity was normalized to TRIS $2(200 \mu \mathrm{L})$ incubated with $\mathrm{KO}_{2}(10 \mu \mathrm{L}, 0.14 \mathrm{mM})$.

\subsection{Statistical Analysis.}

The statistical difference between different conditions was evaluated using GraphPad Prism 8 software. A one-way ANOVA with a confidence level of 95\% $(\alpha=0.05)$ using Tukey's multiple comparisons test $\left(* p \leq 0.05 ;{ }^{* *} p \leq 0.01 ; * * * p \leq 0.001 ; * * * * p \leq 0.0001\right)$ was employed.

\section{RESULTS AND DISCUSSION}

\subsection{Fabrication of the Hb-loaded NCs.}

\subsubsection{Fabrication and Characterization of $\mathrm{Hb}^{\mathrm{PDA}}$.}


Despite its excellent $\mathrm{O}_{2}$ binding and releasing properties, $\mathrm{Hb}$ molecules break down into dimers and monomers when administered in their free form, causing severe toxicity. ${ }^{1,7}$ Therefore, to avoid Hb's dissociation, we introduce a PDA coating. DA, under mild basic conditions (TRIS 1), has the ability to self-polymerize into PDA onto virtually any type of substrate independent of shape and material. ${ }^{29-31}$ Importantly, unlike other $\mathrm{Hb}$ stabilization methods (e.g., using intra- and intermolecular modifications), ${ }^{1,4}$ PDA coatings closely bond onto Hb's surface with barely any chemical reaction with its functional groups. Additionally, we, and others, have demonstrated that PDA has ROS scavenging abilities. ${ }^{27,32}$ The incorporation of PDA has been previously employed to minimize the oxidation of HBOCs. Specifically, individual $\mathrm{Hb}$ molecules have been PDAcoated, but also larger particles fully made of $\mathrm{Hb}^{33-36}$

Herein, Hb's coating by PDA was conducted employing a weight ratio 5:1 of $\mathrm{Hb}$ and DA for $3 \mathrm{~h}$. Figure 1A shows how the colour of the suspension changed over time from red to dark brown, thereby demonstrating the DA polymerization into PDA. The size of the $\mathrm{Hb}^{\mathrm{PDA}}$, as evaluated by DLS, showed a slight increase from $5.2 \mathrm{~nm}$ (for uncoated $\mathrm{Hb}$ ) to $7.0 \mathrm{~nm}$ (for $\mathrm{Hb}^{\mathrm{PDA}}$ ) (Figure 1B). The size distribution furthermore indicates individual PDA-coated $\mathrm{Hb}$ molecules instead of $\mathrm{Hb}^{\mathrm{PDA}}$ aggregates. This is in agreement with Wang et al., which showed a similar hydrodynamic size for PDA-coated $\mathrm{Hb}$, obtaining a $\sim 1-2 \mathrm{~nm}$ size increase after coating, and using the same PDA polymerization conditions. ${ }^{34}$

Proteins secondary structure is central to their function, and preservation of this structure is a strong indication for preserved protein activity. Thus, FTIR spectroscopy was used to evaluate Hb's functional regions following PDA coating (Figure 1C). The comparison of FTIR spectra of Hb and $\mathrm{Hb}^{\mathrm{PDA}}$ shows how both spectra display almost identical bands at $1642 \mathrm{~cm}^{-1}$ (amide I) and $1530 \mathrm{~cm}^{-}$ ${ }^{1}$ (amide II). Preservation of wavenumbers or band ratios for both amide I (corresponding to $\mathrm{C}=\mathrm{O}$ stretching) and amide II (corresponding to N-H bending and C-N stretching) indicates that Hb's chemical structure is well maintained following PDA coating. The bands of the PDA spectrum at $875 \mathrm{~cm}^{-1}$ and $809 \mathrm{~cm}^{-1}$ correspond to the three and the five substituted benzene stretching vibrations, respectively. While previous reports have shown increase in adsorption for the bands at $875 \mathrm{~cm}^{-1}$ and $809 \mathrm{~cm}^{-1}$ following PDA coating, ${ }^{33}$ the two bands are not present in our $\mathrm{Hb}^{\mathrm{PDA}}$ spectrum. We attribute the absence of these bands to the deposition of a thinner PDA coating due to the usage of a lower DA concentration. Hb's secondary structure following coating with PDA 
was further investigated by CD in the range of 197 to $260 \mathrm{~nm}$ (Figure 1D). The CD spectrum of $\mathrm{Hb}^{\mathrm{PDA}}$ is almost identical to the spectrum of $\mathrm{Hb}$. Both spectra show two absorption bands at 209 and $220 \mathrm{~nm}$, which are characteristic for $\alpha$-helical structures ${ }^{37}$ Such a similar helicity for the PDAcoated $\mathrm{Hb}$ indicates preservation of $\mathrm{Hb}$ 's secondary structure. As control, $\mathrm{Hb}$ heated to $60{ }^{\circ} \mathrm{C}$ (as a model of partially denatured $\mathrm{Hb}$ ) and $\mathrm{Hb}$ heated to $100{ }^{\circ} \mathrm{C}$ (as a model of fully denatured $\mathrm{Hb}$ ) were considered. Here, it can be observed denaturation leads to a large dip in intensity and, eventually, complete loss of the of the $\alpha$-helix structure.

The effect of the PDA coating on Hb's native bioactivity was also investigated by monitoring the ability of $\mathrm{Hb}^{\mathrm{PDA}}$ to reversibly bind and release $\mathrm{O}_{2}$. Figure $\mathbf{2 A}$ shows how the initial $\mathrm{Hb}^{\mathrm{PDA}}\left(\mathrm{O}_{2}\right.$ cycle 1) displays the characteristic adsorption bands of oxy-Hb. Specifically, a main band at 409 $\mathrm{nm}$ (Søret peak) and two additional bands in the visible region (at $539 \mathrm{~nm}$ and $575 \mathrm{~nm}$ ) can be observed. Next, following purging with nitrogen gas $\left(\mathrm{N}_{2}-\right.$ cycle 1$)$, the Søret band shifted to 427 $\mathrm{nm}$, and a single band appeared at $553 \mathrm{~nm}$, indicating the presence of deoxygenated Hb. Following on, the deoxygenated $\mathrm{Hb}^{\mathrm{PDA}}$ was purged with compressed air, resulting in the appearance of the oxy- $\mathrm{Hb}$ absorbance bands and demonstrating the ability of $\mathrm{Hb}^{\mathrm{PDA}}$ to reversibly bind and release $\mathrm{O}_{2}$. After 3 weeks of storage at $4{ }^{\circ} \mathrm{C}$, the $\mathrm{Hb}^{\mathrm{PDA}}$ samples still showed this reversibility (Figure S3). A second $\mathrm{N}_{2}$ cycle and a third $\mathrm{O}_{2}$ cycle were also conducted, and the changes in the UV-Vis spectra highlighting the ability of $\mathrm{Hb}^{\mathrm{PDA}}$ to bind and release $\mathrm{O}_{2}$ over multiple rounds. Exposure to carbon monoxide (CO) gas was also evaluated. A shift in the Søret band to $417 \mathrm{~nm}$ together with the shift of the two visible-bands to $537 \mathrm{~nm}$ and $568 \mathrm{~nm}$, demonstrate the conversion of oxy-Hb to CO-Hb.

To get a deeper insight on the $\mathrm{O}_{2}$ binding abilities of $\mathrm{Hb}^{\mathrm{PDA}}$, the ODC of $\mathrm{Hb}^{\mathrm{PDA}}$ was assessed. Figure 2B shows the dependency of $\mathrm{Hb}$ 's saturation with $\mathrm{O}_{2}$ on the $\mathrm{pO}_{2}$ with a sigmoidal shape, indicating cooperative $\mathrm{O}_{2}$ binding for both free $\mathrm{Hb}$ and the PDA-coated $\mathrm{Hb}^{\mathrm{PDA}}$. The oxygen equilibrium parameter $\mathrm{p} 50$, which is the $\mathrm{pO}_{2}$ at which $50 \% \mathrm{O}_{2}$ saturation is achieved, was 20.9 $\mathrm{mmHg}$ for free $\mathrm{Hb}$. A decrease in p50 to $15.3 \mathrm{mmHg}$ was observed following PDA coating, which indicates increased $\mathrm{O}_{2}$ affinity for $\mathrm{Hb}^{\mathrm{PDA}}$. It could be hypothesized that the PDA coating restricts $\mathrm{Hb}$ 's movement from the relaxed and oxygenated state into the tense and deoxygenated one. This could subsequently result in $\mathrm{O}_{2}$ release at a lower $\mathrm{pO}_{2}$ as compared to free $\mathrm{Hb}$. Achieving low p50 is beneficial when developing HBOCs since it minimizes premature $\mathrm{O}_{2}$ release in the precapillary arterioles, thus maximizing $\mathrm{O}_{2}$ supply in hypoxic tissues. The Hill coefficient $(n)$, calculated as 1.2 
(and 2.1 for free $\mathrm{Hb}$ ) is similar to previously reported $n$-values for HBOCs. ${ }^{38,39}$ Although there is a decrease in $n$ following PDA coating, cooperativity is still retained $(n>1)$. The cooperativity is a result of subunit-subunit interaction, ${ }^{40}$ thereby indicating that the tetrameric $\mathrm{Hb}$ structure was not degraded into monomers after PDA coating. Thus, $\mathrm{O}_{2}$ binding to one of the heme groups of $\mathrm{Hb}^{\mathrm{PDA}}$, results in increased $\mathrm{O}_{2}$ affinity for the remaining free hemes, facilitating maximum $\mathrm{O}_{2}$ loading. In turn, $\mathrm{O}_{2}$ release decreases the $\mathrm{O}_{2}$ binding affinity of the remaining ligated hemes, thus facilitating complete $\mathrm{O}_{2}$ release.

\subsubsection{Fabrication and Characterization of $\mathrm{CeO}_{2}-\mathrm{NPs}$.}

Over time, $\mathrm{Hb}$ auto-oxidizes into metHb which results in impaired $\mathrm{O}_{2}$ binding and releasing properties and oxidative side reactions mediated by the heme group. ${ }^{14}$ Within biological RBCs, $\mathrm{Hb}$ conversion into metHb is prevented by a multi-faceted antioxidant system. Our approach however is to employ nanozymes, a novel type of nanoparticulate systems displaying enzyme-like properties but overcoming the limitations of biological enzymes such as short half-life, environmental sensitivity, and high production costs. ${ }^{21,23}$ Additionally, nanozymes exhibit better recyclability over their natural counterparts, which is a crucial aspect if they are expected to prevent metHb conversion over an extended period of time. In particular, $\mathrm{CeO}_{2}-\mathrm{NPs}_{\text {sere }}$ chosen as antioxidant nanozymes. Within $\mathrm{CeO}_{2}-\mathrm{NPs}$, $\mathrm{Ce}(\mathrm{III})$ and $\mathrm{Ce}(\mathrm{IV})$ oxidative states co-exist, producing a redox couple. ${ }^{41}$ This interchange between valence states of the Ce atoms makes it possible for the $\mathrm{CeO}_{2}$-NPs to react catalytically with $\mathrm{H}_{2} \mathrm{O}_{2}$ and $\mathrm{O}_{2}{ }^{-}$, thereby replacing the functions that are normally performed by CAT and SOD, respectively.

Thus, $\mathrm{CeO}_{2}-\mathrm{NPs}$ were synthesized and characterized for their catalytic activity. The as-prepared $\mathrm{CeO}_{2}-\mathrm{NPs}$ displayed a hydrodynamic diameter of $2.6 \pm 0.5 \mathrm{~nm}$, a $0.568 \mathrm{PDI}$, and a $\zeta$-potential of $-26 \pm 7 \mathrm{mV}$ (Figure 3A). TEM imaging showed that the $\mathrm{CeO}_{2}-\mathrm{NPs}$ were monodisperse with an average size of $2.2 \mathrm{~nm}$ (Figure 3B), which is in agreement with the size obtained using DLS. The crystalline nature of the $\mathrm{CeO}_{2}-\mathrm{NP}$ was directly observable in Figure $3 \mathrm{C}$, showing a phase contrast image of an individual $\mathrm{CeO}_{2}-\mathrm{NP}$ oriented along the [110] zone axis. The (111) interplaner spacing measured $0.31 \mathrm{~nm}$ corresponding to $\mathrm{CeO}_{2}$. TEM-SAD was performed to further confirm the crystallinity of the $\mathrm{CeO}_{2}$-NPs. A polycrystalline SAD pattern (Figure 3D) was obtained with 
diffraction rings corresponding to the $\mathrm{Fm} \overline{3} \mathrm{~m}$ space group with lattice parameter $\mathrm{a}=0.54 \mathrm{~nm}$, which matches well with $\mathrm{CeO}_{2}$ 's fluorite crystal structure $(\mathrm{Fm} \overline{3} \mathrm{~m}, \mathrm{a}=0.54 \mathrm{~nm}){ }^{42}$

Next, the antioxidant activity of the $\mathrm{CeO}_{2}-\mathrm{NPs}$ was assessed. First the SOD-like activity, measured by the ability of the $\mathrm{CeO}_{2}$-NPs to scavenge $\mathrm{O}_{2}{ }^{-}$over time, was evaluated using the WST-1 assay and compared to the natural enzyme (Figure 4A). Within this assay, $\mathrm{O}_{2}$ is converted into $\mathrm{O}_{2}{ }^{--}$by the xanthine/ XO system (Figure 4Ai). $\mathrm{O}_{2}{ }^{-}{ }^{-}$oxidizes the WST-1 reagent into formazan which can be detected by UV-Vis at $450 \mathrm{~nm}$. However, SOD-like activity of the $\mathrm{CeO}_{2}-\mathrm{NPs}$ or native SOD converts the $\mathrm{O}_{2}{ }^{\circ-}$ into $\mathrm{O}_{2}$ and $\mathrm{H}_{2} \mathrm{O}_{2}$, thereby decreasing the amount of $\mathrm{O}_{2}{ }^{-}$present in the system, and thus subsequently decreasing the amount of oxidized formazan being produced. An increase in both $\mathrm{CeO}_{2}$-NPs and SOD concentrations results in an enhanced $\mathrm{O}_{2}{ }^{-}$removal, as shown by the decreased nAbs values (Figure 4Aii). Almost complete $\mathrm{O}_{2}{ }^{--}$depletion is achieved since a maximum reduction to $7 \% \mathrm{nAbs}$ is observed for concentrations of $1 \mathrm{mM} \mathrm{CeO}_{2}-\mathrm{NPs}$ and $50 \mathrm{U} \mathrm{mL}^{-}$ ${ }^{1} \mathrm{SOD}$. Additionally, the SOD-like activity of $\mathrm{CeO}_{2}-\mathrm{NPs}$ stored in solution at $4{ }^{\circ} \mathrm{C}$ was shown to be maintained for at least over a period of 21 days (Figure 4Aiii).

The CAT-like activity of the $\mathrm{CeO}_{2}$-NPs was investigated by measuring their $\mathrm{H}_{2} \mathrm{O}_{2}$ scavenging ability using the Amplex Red assay and compared to that of the biological enzyme (Figure 4B). Within this assay, $\mathrm{H}_{2} \mathrm{O}_{2}$ acts as a co-substrate for the conversion of the Amplex Red reagent, in presence of HRP, into the fluorescent resorufin product (Figure 4Bi). CAT-like activity of the $\mathrm{CeO}_{2}$-NPs or native CAT converts $\mathrm{H}_{2} \mathrm{O}_{2}$ into $\mathrm{H}_{2} \mathrm{O}$ and $\mathrm{O}_{2}$, thereby decreasing the amount of $\mathrm{H}_{2} \mathrm{O}_{2}$ present in the system, and subsequently decreasing the amount of resorufin product being produced. Figure 4Bii shows that increasing concentrations of both $\mathrm{CeO}_{2}-\mathrm{NPs}$ and CAT result in decreased $\mathrm{H}_{2} \mathrm{O}_{2}$ amounts, as indicated with the lower nFI values. While, for $\mathrm{CeO}_{2}-\mathrm{NPs}$, plateau values of $\sim 17 \%$ in $\mathrm{nFI}$ were obtained for a concentration $0.5 \mathrm{mM}$; complete $\mathrm{H}_{2} \mathrm{O}_{2}$ depletion was detected for a concentration of $12 \mathrm{U} \mathrm{mL}^{-1} \mathrm{CAT}$. Although, in this case, complete $\mathrm{H}_{2} \mathrm{O}_{2}$ depletion was obtained only with the natural enzyme, the $\mathrm{H}_{2} \mathrm{O}_{2}$ scavenging ability of $\mathrm{CeO}_{2}-\mathrm{NPs}$ remained almost unchanged for a period of at least 21 days when stored in solution at $4{ }^{\circ} \mathrm{C}$ (Figure 4 Biii). In contrast, the CAT enzyme experiences a complete loss of catalytic activity within 20 days when stored at $4{ }^{\circ} \mathrm{C} .{ }^{43}$ Therefore, the long-term stability of the antioxidant properties of $\mathrm{CeO}_{2}-\mathrm{NPs}$ makes them particularly interesting for the fabrication of HBOCs with long shelf life. 


\subsubsection{Fabrication and Characterization of the Hb-loaded NCs.}

Different HBOCs encapsulation strategies have been developed, including lipidic, ${ }^{10}$ polymeric, ${ }^{11}$ and MOF-based platforms. MOFs feature well-defined pore structures which allow for high $\mathrm{Hb}$ encapsulation. ${ }^{13}$ Interestingly, zinc-based MOFs were shown to protect the encapsulated $\mathrm{Hb}$ against oxidation by $\mathrm{H}_{2} \mathrm{O}_{2} \cdot{ }^{44} \mathrm{Hb}$ has been also encapsulated within lipidic vesicles, also known as liposomes. Such a system has already been widely evaluated in pre-clinical models showing circulation lives up to $65.2 \mathrm{~h}$ and up to $72 \mathrm{~h}$ in rabbits and monkeys, respectively. ${ }^{45,46}$ Herein, however, the polymeric platform is chosen. Polymeric NPs are more flexible in encapsulating different entities, due to their high tunability and choice in materials. Specifically, the LbL technique, which involves the alternating deposition of interacting entities (e.g., polymers but also NPs or liposomes) onto a core allows for these complex systems. ${ }^{47-49}$ Thus, the LbL technique was employed to incorporate the $\mathrm{Hb}^{\mathrm{PDA}}$ and $\mathrm{CeO}_{2}-\mathrm{NPs}$ onto PLGA-NPs.

Negatively charged PLGA-NPs with a $\zeta$-potential of $-19 \mathrm{mV}$, an average hydrodynamic size of $217 \mathrm{~nm}$, and a 0.042 PDI were synthesized. However, their negative charge does not allow for the adsorption of $\mathrm{Hb}^{\mathrm{PDA}}$ and $\mathrm{CeO}_{2}-\mathrm{NPs}$, which are also negatively charged. Thus, a PDA layer which will shield the environment from the organic core while also facilitating surface modification, ${ }^{50}$ is first deposited (PLGA/PDA-NCs). An increase in $\zeta$-potential (to $-15 \mathrm{mV}$ ) and the dark appearance of the PLGA/PDA-NCs, as shown in the inset, confirmed the successful deposition of PDA (Figure 5A). Next, in order to achieve charge reversal to allow for the deposition of the negatively charged $\mathrm{Hb}^{\mathrm{PDA}}$ and $\mathrm{CeO}_{2}-\mathrm{NPs}$, PLL intermediate layers were deposited. PLL was chosen since, apart from being a positively charged and biocompatible polymer, it allows for Michael-type addition and Schiff-base formation with the catechol moieties of the PDA layer, thus creating strong chemical bonding between the layers. ${ }^{50}$ As shown in Figure $5 \mathrm{~A}$, the $\zeta$-potential became positive $(+14 \mathrm{mV})$ after PLL deposition. Next, the $\mathrm{Hb}^{\mathrm{PDA}}$ layer resulted in PLGA/Hb ${ }^{\mathrm{PDA}}-\mathrm{NCs}$ with a $\zeta$-potential of $-16 \mathrm{mV}$, indicating a successful adsorption. PLL was used again as a positively charged separation layer $(+10 \mathrm{mV})$, followed by the deposition of $\mathrm{CeO}_{2}-\mathrm{NPs}_{\mathrm{s}}$ which rendered a negative $\zeta$-potential of $-19 \mathrm{mV}$ (PLGA/ $\left.\mathrm{Hb}^{\mathrm{PDA}} /\left(\mathrm{CeO}_{2}-\mathrm{NPs}\right)-\mathrm{NCs}\right)$. Finally, to obtain Hb-loaded NCs with a stealth coating, the positively charged copolymer PLL-g-PEG was deposited onto the $\mathrm{NCs}$ yielding PLGA/ $\mathrm{Hb}^{\mathrm{PDA}} /\left(\mathrm{CeO}_{2}-\mathrm{NPs}\right) / \mathrm{PEG}-\mathrm{NCs}$ with a final overall charge of $+9 \mathrm{mV}$. The loading of $\mathrm{Hb}$ and $\mathrm{CeO}_{2}$-NPs was quantified by ICP-MS. Specifically, $150.3 \pm 26.7 \mu \mathrm{g} \mathrm{Hb}$ had 
been entrapped within a $\mathrm{NC}$ as shown by measuring the iron content. $0.213 \pm 0.007 \mu \mathrm{mol} \mathrm{CeO}_{2}$ NPs were incorporated per NC as shown by measuring the cerium content by ICP-MS.

The final PLGA/ $\mathrm{Hb}^{\mathrm{PDA}} /\left(\mathrm{CeO}_{2}-\mathrm{NPs}\right) / \mathrm{PEG}-\mathrm{NCs}$ had an average hydrodynamic diameter of $269 \mathrm{~nm}$, with a 0.055 PDI. DIC imaging furthermore showed a monodisperse suspension (Figure 5Bi) while cryo-TEM imaging confirmed the presence of the deposited $\mathrm{CeO}_{2}-\mathrm{NPs}$ (Figure 5Bii), which are presented as dots on the surface of the nanocarrier (as indicated by the black arrows). While the $\mathrm{CeO}_{2}$-NPs were mainly deposited in a monodisperse way, bigger $\mathrm{CeO}_{2}-\mathrm{NPs}$ aggregates on top of the NCs could also be observed (open arrow). We suggest that aggregation could be due to the presence of $\mathrm{NaCl}$ in the final TRIS 2 where the NCs are suspended, which has been previously reported to have an aggregation effect onto citrate-stabilized particles. ${ }^{51}$

\subsection{Evaluation of the Stealth Coating.}

To improve the circulation time of nanoparticulate systems, surface PEGylation is a wellestablished strategy. PEGylation prevents opsonisation by blocking protein-binding sites and/or creating steric hindrance due to its flexible hydrophilic polymer chains. In this study, PEGylation was easily achieved by coating the LbL-assembled nanocarrier with PLL-g-PEG. This comb-like copolymer was chosen to provide sufficient electrostatic binding sites between PLL backbone and the PLGA/Hb ${ }^{\mathrm{PDA}} /\left(\mathrm{CeO}_{2}-\mathrm{NPs}\right)-\mathrm{NCs}$, while the non-ionic hydrophilic PEG chains extend outwards, providing antifouling properties. ${ }^{52}$

To assess the effect of PEGylation as stealth coating, a protein adsorption study was performed. Uncoated PLGA/Hb ${ }^{\mathrm{PDA}} /\left(\mathrm{CeO}_{2}-\mathrm{NPs}\right)-\mathrm{NCs}$ and PEGylated PLGA/Hb ${ }^{\mathrm{PDA}} /\left(\mathrm{CeO}_{2}-\mathrm{NPs}\right) / \mathrm{PEG}-\mathrm{NCs}$ were incubated in albumin and immunoglobulin solutions $\left(\mathrm{BSA}^{\mathrm{F}}\right.$ and $\operatorname{IgG}^{\mathrm{F}}$, respectively), which are the most abundant proteins in blood. ${ }^{27}$ The results show a different PEGylation effect depending on the studied protein (Figure 6A). In particular, the absorption of $\mathrm{BSA}^{\mathrm{F}}$ onto the NCs is very limited independently of the end coating. As such, both PLGA/ $\mathrm{Hb}^{\mathrm{PDA}} /\left(\mathrm{CeO}_{2}-\mathrm{NPs}\right)-\mathrm{NCs}$ and PLGA $/ \mathrm{Hb}^{\mathrm{PDA}} /\left(\mathrm{CeO}_{2}\right.$-NPs $) / \mathrm{PEG}-\mathrm{NCs}$ experience only a $15 \%$ increase in $\mathrm{nFI}$ as compared to the controls (NCs without protein exposure). While we attribute the low adsorption onto $\mathrm{PLGA} / \mathrm{Hb}^{\mathrm{PDA}} /\left(\mathrm{CeO}_{2}-\mathrm{NPs}\right) / \mathrm{PEG}-\mathrm{NCs}$ to the stealth properties of the PEG coating, previous results have shown little to non-significant BSA adsorption for negatively charged $\mathrm{CeO}_{2}-\mathrm{NPs}$, which has been attributed to their electrostatic repulsion. ${ }^{53}$ In contrast, for $\mathrm{IgG}^{\mathrm{F}}$, PEGylation has a tremendous 
impact with similar $\mathrm{nFI}$ readings for the PEGylated NCs (11\%) and the control (9\%). In contrast, a $91 \%$ increase in $\mathrm{nFI}$ is observed for the uncoated NCs. As shown by Zhang et al., IgG type proteins have the ability to destroy the citrate ligands of citrated-capped inorganic NPs, subsequently binding onto the inorganic core. ${ }^{54}$ Furthermore, during the destruction of the citrate ligands, the inorganic NPs cores are temporarily exposed, which can lead to the irreversible aggregation of the NPs as a result of the strong van der Waals interactions. ${ }^{54}$ This aggregation will then translate into accelerated clearance by the MPS.

The effect of PEGylation was also assessed in vitro by means of cell association studies. Two model cell lines, RAW 264.7 macrophages and HUVEC endothelial cell lines were used. Macrophages are the first line of defense against intruding pathogens, while endothelial cells line the inside of the blood vessels. The cells were exposed to uncoated PLGA $/ \mathrm{Hb}^{\mathrm{PDA}} /\left(\mathrm{CeO}_{2}-\mathrm{NPs}\right)-$ NCs and PEGylated PLGA/Hb ${ }^{\mathrm{PDA}} /\left(\mathrm{CeO}_{2}-\mathrm{NPs}\right) / \mathrm{PEG}-\mathrm{NCs}$, and the CUE and CMFI of the cells incubated for $4 \mathrm{~h}$ with different amounts of NCs, were evaluated. The CUE shows a slight increase upon incrementing the amount of NCs for both cell lines and for both uncoated and PEGylated NCs (Figure 6B). Importantly, for both cell lines, there is a significant decrease in CUE following incubation with the PEGylated NCs as compared to the uncoated counterparts. Such a decrease in CUE ranges from $23 \%$ (for HUVEC cells exposed to $7.5 \times 10^{6} \mathrm{NCs} \mathrm{mL}^{-1}$ ) to up to $46 \%$ (for RAW 264.7 cells exposed to $1.5 \times 10^{6} \mathrm{NCs} \mathrm{mL}^{-1}$ ). The $\mathrm{nCMFI}$ readings are in agreement with the CUE results (Figure 6C), showing a decrease in nCMFI when both cell lines are incubated with the PEGylated NCs. This decrease in nCMFI ranges from 8\% (for HUVEC cells exposed to $7.5 \times 10^{6}$ $\mathrm{NCs} \mathrm{mL}^{-1}$ ) to up to $48 \%$ (for RAW 264.7 cells exposed to $7.5 \times 10^{6} \mathrm{NCs} \mathrm{mL}^{-1}$ ). Thus, functionalization with PLL- $g$-PEG rendered NCs with substantial stealth properties for both cell lines and for all the studied concentrations.

\subsection{Biocompatibility.}

To get a deeper insight on the interaction of the NCs with the two cell lines, the cell viability following incubation with increasing concentrations of PLGA $/ \mathrm{Hb}^{\mathrm{PDA}} /\left(\mathrm{CeO}_{2}-\mathrm{NPs}\right) / \mathrm{PEG}-\mathrm{NCs}$ was evaluated. Figure 7 shows a significant decrease in nCV only for RAW 264.7 cells in the presence of the highest concentration of NCs. In contrast, the results for HUVEC cells were very different and increasing $\mathrm{nCV}$ readings were observed for increasing amounts of NCs. We suggest that this 
decrease in CV for RAW 264.7 could be a result of the NCs being engulfed by the cells instead of associated with the cell membrane. As opposed to HUVEC cells, macrophages are specialized cells that engulf and digest foreign substances. Enhanced CV as shown for HUVECs, has also been observed for other HBOCs following incubation with cells. ${ }^{36}$ Such an enhanced CV was attributed to the $\mathrm{O}_{2}$ carrying properties of the encapsulated $\mathrm{Hb}$, thereby supplying $\mathrm{O}_{2}$ to the cell environment and subsequently facilitating cell viability.

In addition to macrophages and endothelial cells, the interaction of nanoparticles with blood cells is an important factor to consider when fabricating NCs to be intravenously administered. The impact of both uncoated PLGA/ $\mathrm{Hb}^{\mathrm{PDA}} /\left(\mathrm{CeO}_{2}-\mathrm{NPs}\right)-\mathrm{NCs}$ and PEGylated PLGA/Hb ${ }^{\mathrm{PDA}} /\left(\mathrm{CeO}_{2}\right.$ NPs)/PEG-NCs on RBCs was assessed by a hemolysis rate test. The Hb-loaded NCs showed haemolysis rates well below 5\% for both NCs at all studied concentrations (Figure 8A). This is an important fact since biomaterials are considered non-hemolytic for haemolysis rates lower than $5 \% .{ }^{11}$ Photographic images of the collected supernatants shows a red coloration only for the positive control, indicating the presence of free $\mathrm{Hb}$ due to erythrocyte haemolysis (Figure 8B). DIC imaging furthermore shows no apparent change in the blood cells morphology following incubation with PLGA/Hb ${ }^{\mathrm{PDA}} /\left(\mathrm{CeO}_{2}-\mathrm{NPs}\right) / \mathrm{PEG}-\mathrm{NCs}$ as compared to the negative control (Figure 8C). Interestingly, even though no apparent effect on the haemolysis rate was observed following incubation of the uncoated PLGA $/ \mathrm{Hb}^{\mathrm{PDA}} /\left(\mathrm{CeO}_{2}-\mathrm{NPs}\right)-\mathrm{NCs}$ with the blood cells, NCs appeared as aggregates in the cell suspension and associated with the blood cells. The photographic insets show the suspensions of both NCs after overnight storage. While PEGylated PLGA/Hb ${ }^{\mathrm{PDA}} /\left(\mathrm{CeO}_{2-}\right.$ NPs)/PEG-NCs remain as a monodisperse suspension, sedimentation takes place for the uncoated $\mathrm{PLGA} / \mathrm{Hb}^{\mathrm{PDA}} /\left(\mathrm{CeO}_{2}-\mathrm{NPs}\right)-\mathrm{NCs}$. These results highlight again the importance of the PEG coating which renders low-fouling properties (Figure 6) but also eliminates the NCs aggregation during storage and in presence of cells (Figure 8C).

\subsection{Catalytic Activity.}

After completing the assembly of the PLGA/ $\mathrm{Hb}^{\mathrm{PDA}} /\left(\mathrm{CeO}_{2}-\mathrm{NPs}\right) / \mathrm{PEG}-\mathrm{NCs}$, the catalytic activity as a result of the incorporation of $\mathrm{CeO}_{2}-\mathrm{NPs}$ was evaluated. Figure 9 shows the SOD-like and the combined SOD- and CAT-like activities for the Hb-loaded NCs after each deposition step. In a similar way as when evaluating the catalytic properties of the $\mathrm{CeO}_{2}-\mathrm{NPs}$ in section 3.1.2, the SOD- 
like activity of the NCs was assessed by the WST-1 assay. Figure 9A shows the nAbs readings at three different time-points. For PLGA-NPs, no decrease in nAbs was observed following incubation for 30 and $60 \mathrm{~min}$. In contrast, upon PDA coating a $\sim 25 \%$ decrease in nAbs is observed for the two longest time-intervals. This is not surprising since the antioxidant properties of PDA scavenging various radicals, ROS, and reactive nitrogen species have been previously demonstrated by us, ${ }^{27,36}$ and others. ${ }^{33,35}$ Next, deposition of PDA-coated $\mathrm{Hb}^{\mathrm{PDA}}$ shows additional $\mathrm{O}_{2}{ }^{-}-$scavenging as shown by a $50 \%$ reduction in nAbs as compared to the controls, again highlighting the antioxidant properties of PDA. Importantly, deposition of the $\mathrm{CeO}_{2}-\mathrm{NPs}$ onto the NCs resulted in almost complete depletion of $\mathrm{O}_{2}{ }^{--}$as shown by a $\sim 90 \%$ reduction in nAbs. Following PEGylation, no additional decrease in nAbs could be detected.

Following on, the CAT-like activity of the NCs was investigated by the Amplex Red assay (Figure 9B). With this assay, we first take advantage of the SOD-like activity of the NCs in catalyzing the decomposition of $\mathrm{O}_{2}{ }^{-}$into $\mathrm{H}_{2} \mathrm{O}_{2}$. Next, we measure the scavenging potential of the NCs towards $\mathrm{H}_{2} \mathrm{O}_{2}$. No antioxidant activity was observed for the PLGA-NPs (Figure 9Bi). Interestingly, coating with PDA results on a slight increment in nFI, indicating increase in $\mathrm{H}_{2} \mathrm{O}_{2}$ concentration. Although such an increase is not significant, this trend has been previously reported in our group, ${ }^{27}$ and could possibly be explained by oxidation of PDA in $\mathrm{O}_{2}$-rich solutions, which produces $\mathrm{H}_{2} \mathrm{O}_{2}$ as an $\mathrm{O}_{2}$ reduction product. ${ }^{55}$ Once PDA is in the oxidized state, however, it loses the ROS-generating ability while still retaining radical-scavenging activities. ${ }^{55}$ The $\mathrm{Hb}^{\mathrm{PDA}}$ layer decreases the $\mathrm{nFI}$ continuously over time, with only $15 \% \mathrm{nFI}$ left after 60 minutes. This decrease is thought to be due to the protective PDA coating on the $\mathrm{Hb}^{\mathrm{PDA}}$, which protects $\mathrm{Hb}$ against $\mathrm{H}_{2} \mathrm{O}_{2}$ (Figure S4), and has previously been employed to scavenge ROS in HBOCs systems. ${ }^{33,34}$ We speculate that the different behaviour of the PDA coatings is a result of the different underlying compounds (i.e., PLGA-NPs or $\mathrm{Hb}$ ). We hypothesize that, as a result of the $\mathrm{O}_{2}$ carrying abilities of $\mathrm{Hb}$, the PDA coating could be in an oxidized state prior to incorporation into the NCs and, thus, displays only radical-scavenging properties. Importantly, similar to Figure 9A, the $\mathrm{CeO}_{2}-\mathrm{NPs}$ are responsible for the depletion of the remaining ROS. The decrease in $\mathrm{nFI}$ after deposition of the $\mathrm{CeO}_{2}-\mathrm{NPs}_{\text {s }}$ was furthermore compared to the activity of the free $\mathrm{CeO}_{2}$-NPs. Performing the Amplex Red assay on both the free $\mathrm{CeO}_{2}-\mathrm{NPs}$ and PLGA/Hb ${ }^{\mathrm{PDA}} /\left(\mathrm{CeO}_{2}-\mathrm{NPs}\right)-\mathrm{NCs}$ showed $49 \%$ of the activity was retained after incorporating the $\mathrm{CeO}_{2}$-NPs. While there is a decrease in activity, the $\mathrm{CeO}_{2}-\mathrm{NPs}_{\mathrm{s}}$ were still able to completely remove the ROS, as shown by a decrease in $\mathrm{nFI}$ to zero. Thus, these 
results highlight the robust ability of $\mathrm{CeO}_{2}$-based nanozymes to deplete $\mathrm{ROS}$ such as $\mathrm{O}_{2}{ }^{--}$and $\mathrm{H}_{2} \mathrm{O}_{2}$.

Next, we evaluated whether the PEGylated PLGA $/ \mathrm{Hb}^{\mathrm{PDA}} /\left(\mathrm{CeO}_{2}-\mathrm{NPs}\right) / \mathrm{PEG}-\mathrm{NCs}$ were able to conduct multiple rounds of catalytic activity. Since HBOCs are expected to circulate in the blood for an extended period of time, being able to deplete ROS in a continuous manner will prevent $\mathrm{Hb}$ oxidation into metHb. Figure 9Bii shows that on a first cycle, the PEGylated NCs were able to deplete $75 \%$ of $\mathrm{H}_{2} \mathrm{O}_{2}$ as shown by the decrease in nFI. On a second cycle, $66 \%$ of the total $\mathrm{H}_{2} \mathrm{O}_{2}$ had been depleted, showing a loss of $9 \%$ in catalytic activity. However, after the five subsequent cycles, the NCs were still able to preserve $42 \%$ of catalytic activity. This demonstrates that the developed $\mathrm{Hb}$-loaded NCs are a robust system able to conduct multiple catalytic rounds, even after being subjected to several spinning and resuspension cycles. Together with the storage stability of the $\mathrm{CeO}_{2}$-NPs (Figure 3B, C), this data shows the potential of the nanozymes in replacing the RBC's native antioxidant system in HBOCs. We envision that the prolonged $\mathrm{H}_{2} \mathrm{O}_{2}$ and $\mathrm{O}_{2}{ }^{-}$ scavenging will protect the encapsulated $\mathrm{Hb}$ against metHb conversion, thereby supporting the potential of the synthesized NCs as oxygen carriers.

\section{CONCLUSIONS}

A multi-layered nanocarrier was fabricated and evaluated in the context of oxygen delivering systems. The LbL technique was employed to adsorb different functional components (i.e., $\mathrm{Hb}^{\mathrm{PDA}}$, $\mathrm{CeO}_{2}$-NPs, and PLL-g-PEG) onto a PLGA-NP core. Such combination created a nanocarrier able to reversibly bind and release $\mathrm{O}_{2}$, deplete ROS, and show low-fouling properties.

It was demonstrated that $\mathrm{Hb}$ could be coated with PDA without altering the structure and functionality of the protein. $\mathrm{CeO}_{2}-\mathrm{NPs}$ were synthesized and their ability to deplete $\mathrm{O}_{2}{ }^{-{ }^{-}}$and $\mathrm{H}_{2} \mathrm{O}_{2}$ was demonstrated prior and following incorporation into the nanocarrier. Cryo-TEM imaging was employed to confirm their presence in the nanocarrier system. The long storage stability combined with the catalytic activity over multiple cycles of ROS-scavenging show the $\mathrm{CeO}_{2}-\mathrm{NPs}^{\prime}$ potential as antioxidant system in the new generation of HBOCs. The surface modification using PLL-gPEG resulted in lowered protein adsorption as well a significant reduction in cell association. Finally, the nanocarriers' biocompatibility was demonstrated by cell viability and hemocompatibility tests. Thus, in summary, the fabricated HBOCs can supply oxygen while 
simultaneously providing a robust catalytic system, showing their potential as oxygen delivery systems. 
FIGURES

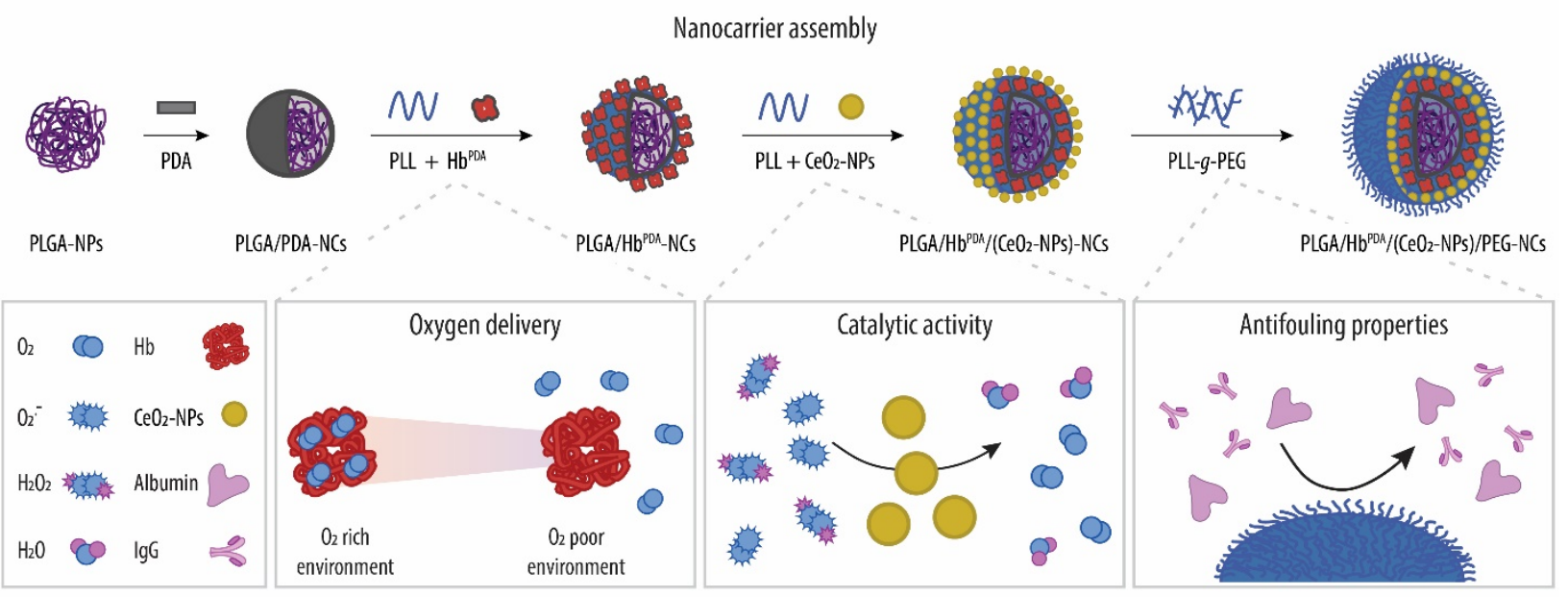

Schematic 1. Schematic illustration of the LbL assembly of Hb-loaded NCs. PLGA-NPs were coated with PDA, PLL, $\mathrm{Hb}^{\mathrm{PDA}}$, PLL, $\mathrm{CeO}_{2}$-NPs, and PLL- $g$-PEG. $\mathrm{Hb}$ is incorporated into the NCs to deliver $\mathrm{O}_{2}$ to cells, while the $\mathrm{CeO}_{2}-\mathrm{NPs}$ scavenge reactive oxygen species such as superoxide radical $\left(\mathrm{O}_{2}{ }^{-}\right)$and hydrogen peroxide $\left(\mathrm{H}_{2} \mathrm{O}_{2}\right)$, which are converted into $\mathrm{O}_{2}$ and $\mathrm{H}_{2} \mathrm{O}$. PEGylation is employed to reduce or eliminate protein (e.g., serum albumin and $\operatorname{IgG}$ ) adsorption. 

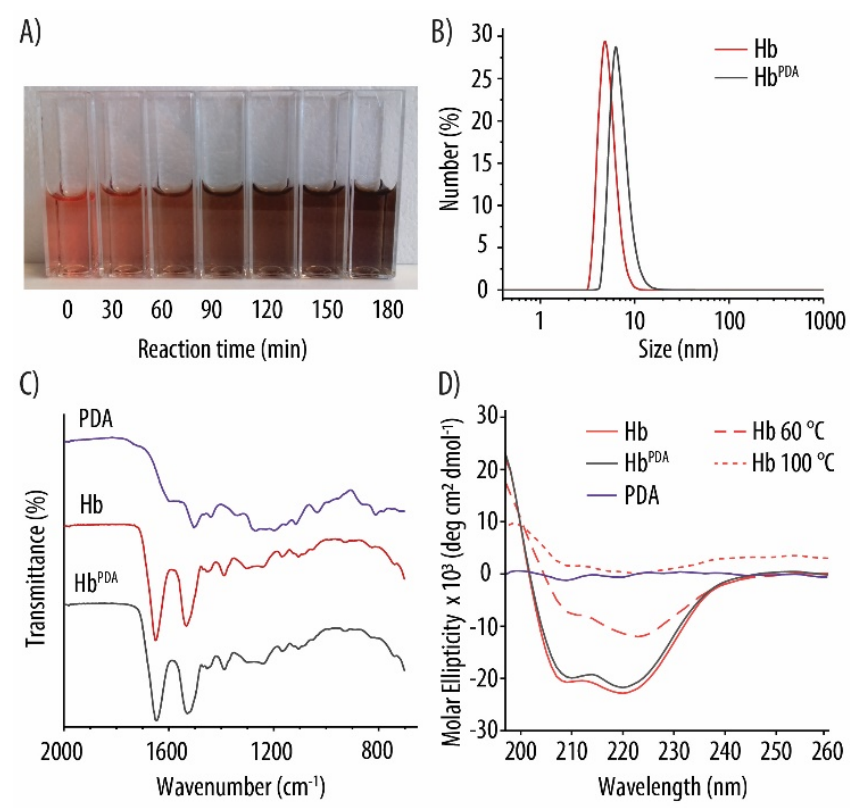

Figure 1. Fabrication and characterization of $\mathrm{Hb}^{\mathrm{PDA}}$. A) Photographic images of the PDA deposition onto $\mathrm{Hb}$ over time as a result of the self-polymerization of DA. B) Hydrodynamic size distribution of bare $\mathrm{Hb}$ and $\mathrm{Hb}^{\mathrm{PDA}}$. C) FTIR spectra of $\mathrm{Hb}, \mathrm{Hb}^{\mathrm{PDA}}$, and PDA only. D) CD spectra of $\mathrm{Hb}, \mathrm{Hb}^{\mathrm{PDA}}$, and PDA only. As controls, partially denatured $\mathrm{Hb}\left(\mathrm{Hb}\right.$ at $\left.60{ }^{\circ} \mathrm{C}\right)$ and fully denatured $\mathrm{Hb}\left(\mathrm{Hb}\right.$ at $\left.100^{\circ} \mathrm{C}\right)$ were considered. 


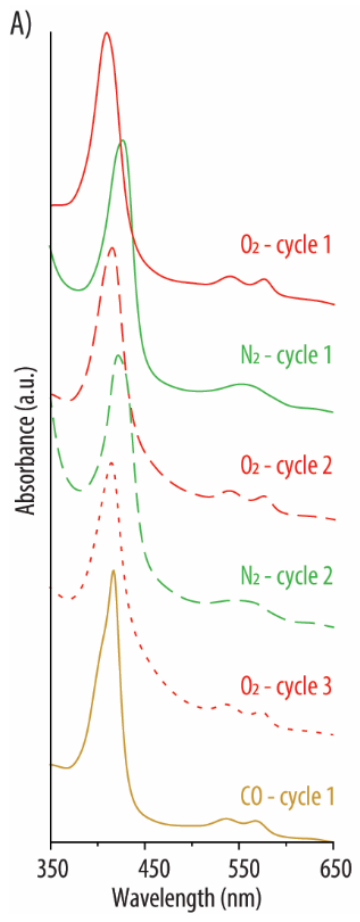

\begin{tabular}{|c|c|c|c|}
\hline \multicolumn{4}{|c|}{ Wavelengths (nm) } \\
\hline $\mathrm{Oxy}-\mathrm{Hb}$ & 412 & 541 & 576 \\
\hline Deoxy-Hb & 428 & \multicolumn{2}{|c|}{555} \\
\hline $\mathrm{CO}-\mathrm{Hb}$ & 419 & 538 & 568 \\
\hline $\mathrm{O}_{2}$ - cycle 1 & 409 & 539 & 575 \\
\hline $\mathrm{N}_{2}$ - cycle 1 & 427 & \multicolumn{2}{|c|}{553} \\
\hline $\mathrm{O}_{2}$ - cycle 2 & 413 & 538 & 574 \\
\hline $\mathrm{N}_{2}$ - cycle 2 & 422 & \multicolumn{2}{|c|}{544} \\
\hline $\mathrm{O}_{2}$ - cycle 3 & 415 & 536 & 573 \\
\hline CO- cycle 1 & 417 & 537 & 568 \\
\hline
\end{tabular}

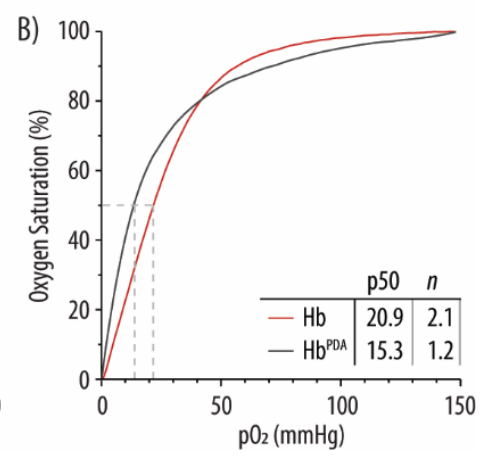

Figure 2. Oxygen carrying capacity of $\mathrm{Hb}^{\mathrm{PDA}}$. A) $\mathrm{UV}-\mathrm{Vis}$ spectra of $\mathrm{Hb}^{\mathrm{PDA}}$ following several cycles of purging with $\mathrm{O}_{2}, \mathrm{~N}_{2}$, and $\mathrm{CO}$. The table shows the band wavelengths of the references (i.e., oxygenated $\mathrm{Hb}(\mathrm{oxy}-\mathrm{Hb})$, deoxygenated $\mathrm{Hb}$ (deoxy-Hb), and $\mathrm{CO}-$ bound $\mathrm{Hb}(\mathrm{CO}-\mathrm{Hb})$ ) and the $\mathrm{Hb}^{\mathrm{PDA}}$ samples. B) ODCs of $\mathrm{Hb}$ and $\mathrm{Hb}^{\mathrm{PDA}}$ with the corresponding $\mathrm{p} 50$ (the $\mathrm{O}_{2}$ partial pressure $\left(\mathrm{pO}_{2}\right)$ at which $50 \%$ of $\mathrm{Hb}$ is saturated with $\left.\mathrm{O}_{2}\right)$ and Hill coefficient $(n)$ values. 

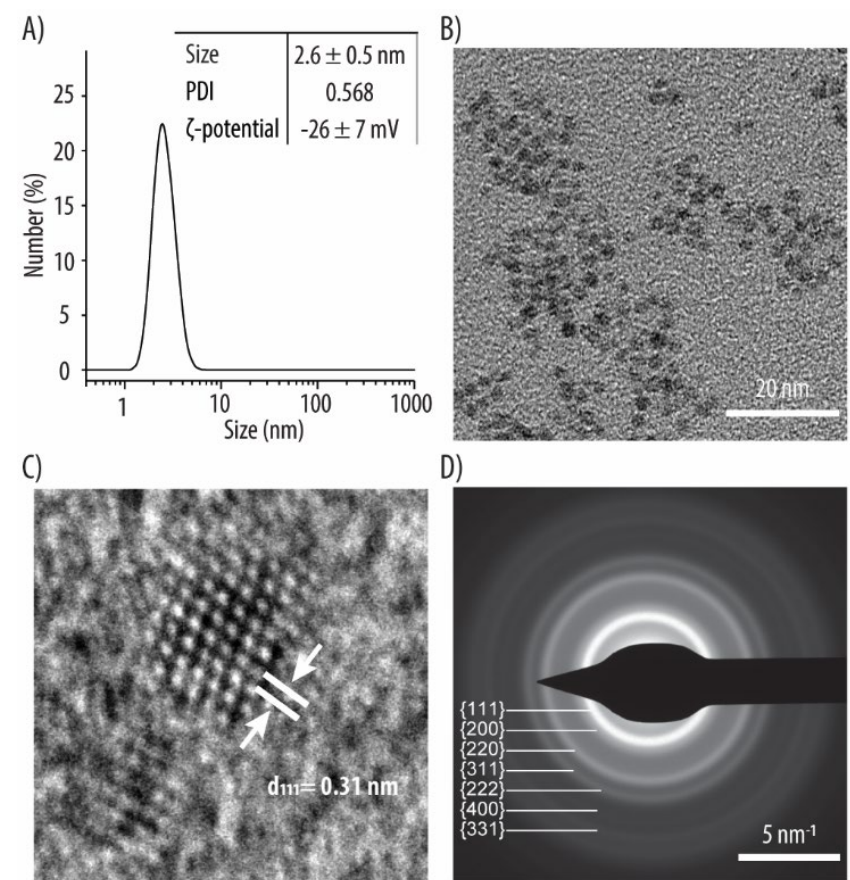
D)

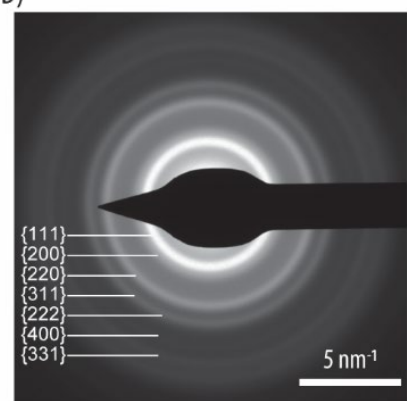

Figure 3. Characterization of $\mathrm{CeO}_{2}$-NPs. A) The hydrodynamic size, PDI, and $\zeta$-potential. B) TEM image of the $\mathrm{CeO}_{2}$-NPs. C) TEM phase contrast image of single $\mathrm{CeO}_{2}-\mathrm{NP}$ showing crystallinity. D) TEM-SAD image with annotated diffraction rings. 


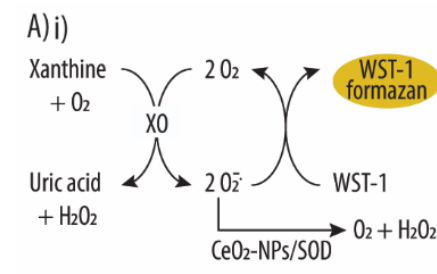

B) i)

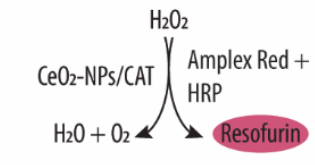

ii)

ii) $\quad$ CAT $\left(\mathrm{U} \mathrm{mL}^{-1}\right)$
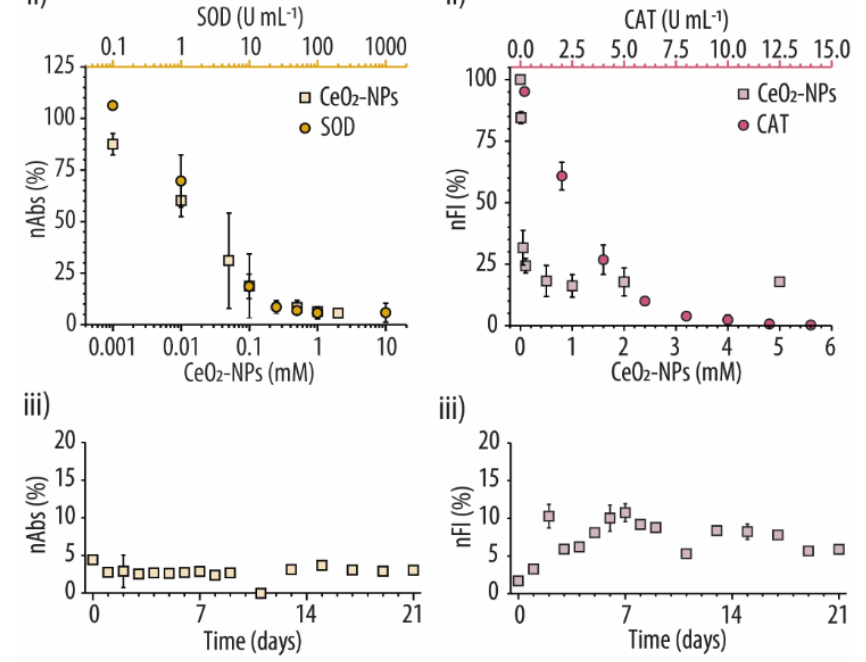

iii)

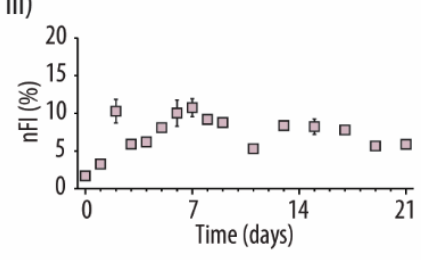

Figure 4. Enzymatic activity of $\mathrm{CeO}_{2}-\mathrm{NPs}$. A) SOD-like activity of $\mathrm{CeO}_{2}-\mathrm{NPs}$ over time measured by the WST-1 assay. i) $\mathrm{O}_{2}$ is converted into $\mathrm{O}_{2}{ }^{--}$by the xanthine/ XO system. $\mathrm{O}_{2}{ }^{-}$oxidizes the WST-1 reagent into formazan which can be detected by UV-Vis at $450 \mathrm{~nm}$. Due to the SOD-like activity of $\mathrm{CeO}_{2}-\mathrm{NPs}, \mathrm{O}_{2}{ }^{-}$is consumed which results in a decrease of the amount of oxidized formazan. The activity of $\mathrm{CeO}_{2}-\mathrm{NPs}$ versus native SOD (ii) and stability of the SOD-like activity of the $\mathrm{CeO}_{2}$-NPs stored at $4{ }^{\circ} \mathrm{C}$ (iii). B) CAT-like activity of $\mathrm{CeO}_{2}-\mathrm{NPs}_{\text {sil }}$ over time measured by the Amplex Red assay. i) $\mathrm{H}_{2} \mathrm{O}_{2}$ interacts with the $\mathrm{CeO}_{2}$-NPs to be converted, as a result of their CATlike activity, into $\mathrm{H}_{2} \mathrm{O}$ and $\mathrm{O}_{2} . \mathrm{H}_{2} \mathrm{O}_{2}$ acts as a co-substrate for the conversion of the Amplex Red reagent into the fluorescent resorufin product in the presence of the enzyme HRP. The activity of $\mathrm{CeO}_{2}-\mathrm{NPs}$ versus native CAT (ii) and stability of the CAT-like activity of the $\mathrm{CeO}_{2}-\mathrm{NPs}_{\text {s }}$ stored at $4{ }^{\circ} \mathrm{C}$ (iii). 


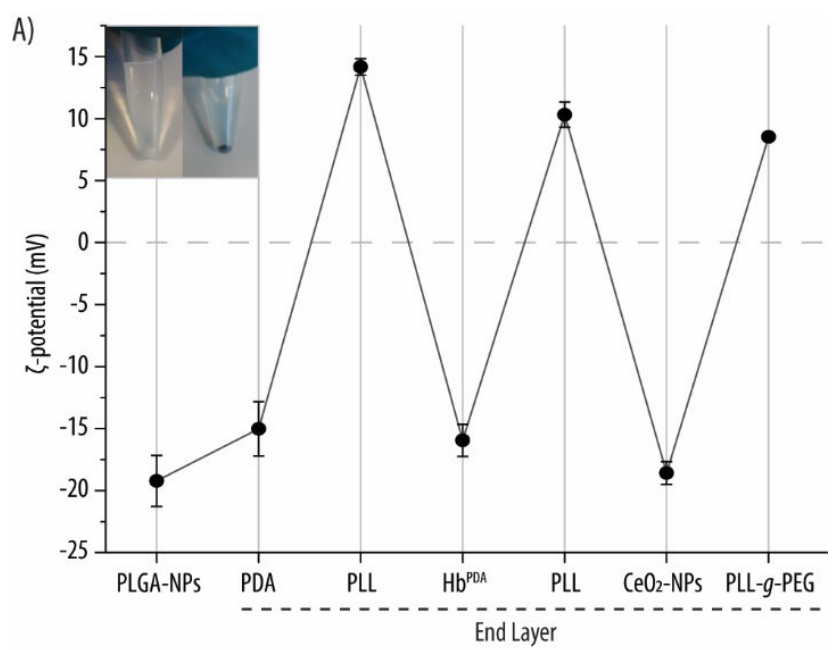

B) i)

ii)
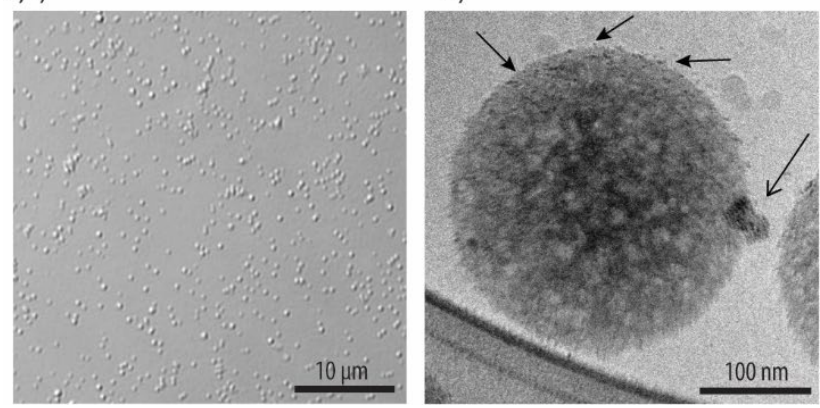

Figure 5. LbL assembly of the Hb-loaded NCs. A) The $\zeta$-potential measurements following subsequent deposition of PDA, PLL, $\mathrm{Hb}^{\mathrm{PDA}}$, PLL, $\mathrm{CeO}_{2}$-NPs, and PLL- $g$-PEG onto the PLGANPs. Inset shows color change of PLGA-NPs after PDA coating. B) Imaging of the final $\mathrm{Hb}-$ loaded NCs using DIC microscopy (i) and cryo-TEM (ii). The cryo-TEM shows the presence of individual $\mathrm{CeO}_{2}$-NPs (black arrows) and a $\mathrm{CeO}_{2}$-NPs aggregate (open arrows). 


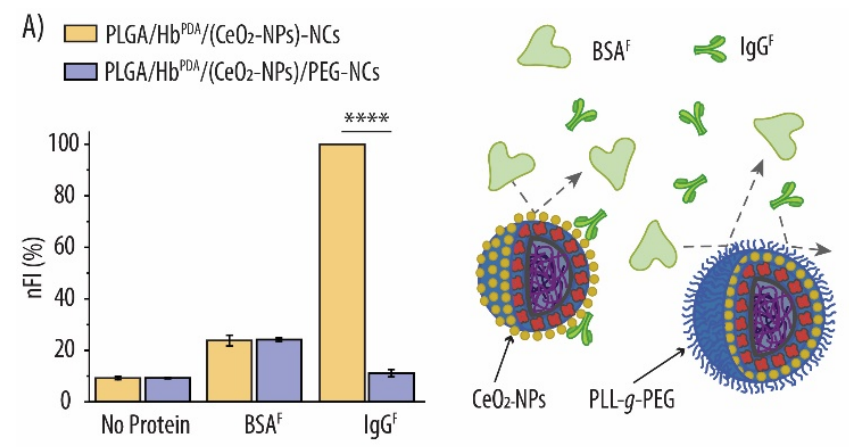

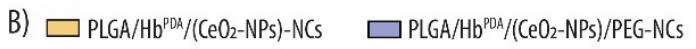

$\begin{array}{ll}\text { i) RAW } 264.7 & \text { ii) HUVEC }\end{array}$

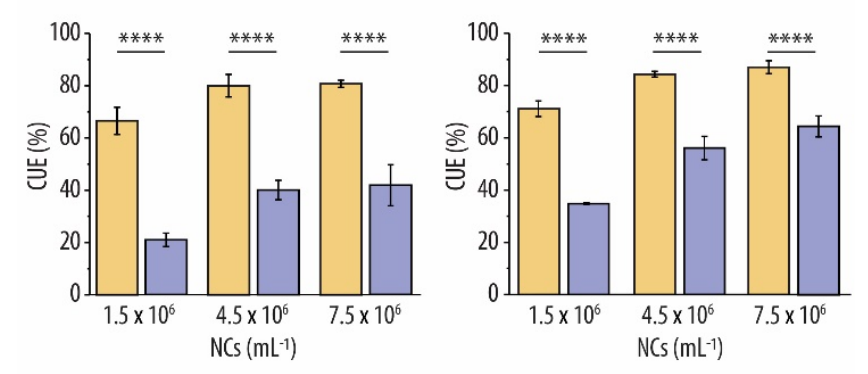

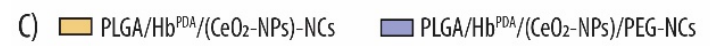

$\begin{array}{ll}\text { i) RAW } 264.7 & \text { ii) HUVEC }\end{array}$

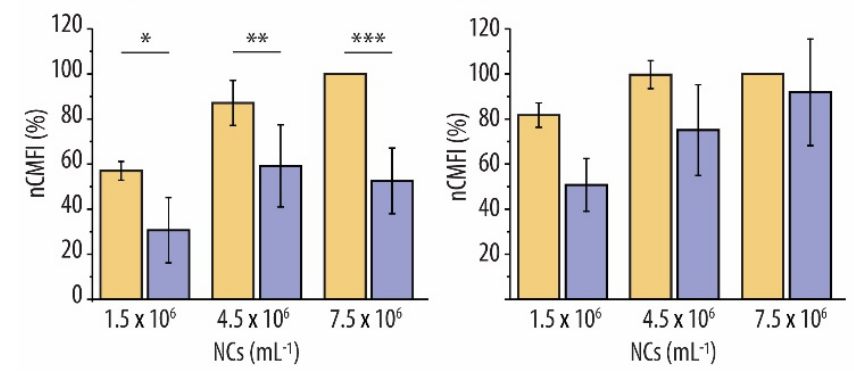

Figure 6. Evaluation of the stealth coating of the Hb-loaded NCs. A) FI readings of PEGylated $\mathrm{PLGA} / \mathrm{Hb}^{\mathrm{PDA}} /\left(\mathrm{CeO}_{2}-\mathrm{NPs}\right) / \mathrm{PEG}-\mathrm{NCs}$ and uncoated $\mathrm{PLGA} / \mathrm{Hb}^{\mathrm{PDA}} /\left(\mathrm{CeO}_{2}-\mathrm{NPs}\right)-\mathrm{NCs}$ following incubation for $4 \mathrm{~h}$ at $37{ }^{\circ} \mathrm{C}$ with $\mathrm{BSA}^{\mathrm{F}}$ and $\operatorname{IgG}^{\mathrm{F}}$. The FI of the NCs without protein exposure were measured as controls. B) CUE of RAW 264.7 (i) and HUVEC (ii) cells exposed to increased amounts NCs. C) nCMFI of RAW 264.7 (i) and HUVEC (ii) cells exposed to increased amounts of NCs. ${ }^{*} p \leq 0.05 ; * * \leq 0.01 ;{ }^{* * *} p \leq 0.001 ; * * * * p \leq 0.0001, \mathrm{PLGA} / \mathrm{Hb}^{\mathrm{PDA}} /\left(\mathrm{CeO}_{2}-\mathrm{NPs}\right)-\mathrm{NCs} v s$ $\mathrm{PLGA} / \mathrm{Hb}^{\mathrm{PDA}} /\left(\mathrm{CeO}_{2}-\mathrm{NPs}\right) / \mathrm{PEG}-\mathrm{NCs}$. 


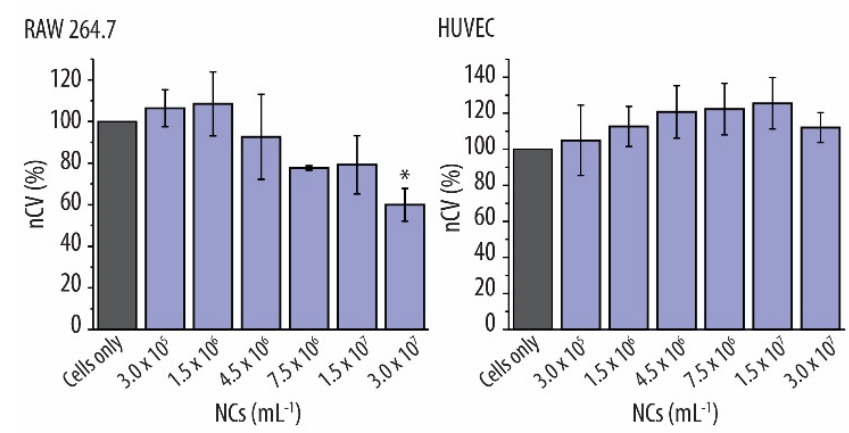

Figure 7. Cell viability in presence of the Hb-loaded NCs. nCV)readings of RAW 264.7 and HUVEC cells following incubation with increasing concentrations of $\mathrm{PLGA} / \mathrm{Hb}{ }^{\mathrm{PDA}} /\left(\mathrm{CeO}_{2}\right.$ NPs)/PEG-NCs for 4 h. ${ }^{*} p \leq 0.05$, NCs $v s$ Cells only. 


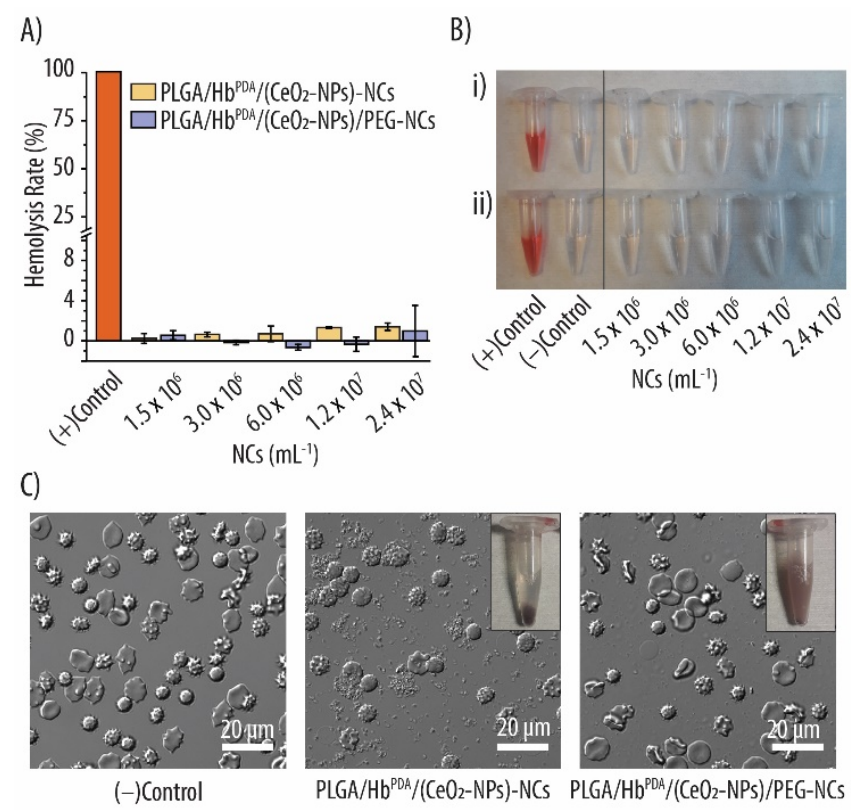

Figure 8. Hemocompatibility of the Hb-loaded NCs. A) Hemolysis rate of uncoated $\mathrm{PLGA} / \mathrm{Hb}^{\mathrm{PDA}} /\left(\mathrm{CeO}_{2}-\mathrm{NPs}\right)-\mathrm{NCs}$ and PEGylated PLGA/Hb ${ }^{\mathrm{PDA}} /\left(\mathrm{CeO}_{2}-\mathrm{NPs}\right) / \mathrm{PEG}-\mathrm{NCs}$ at different concentrations. MQ and PBS were used as positive and negative controls, respectively. B) Photographic images of the supernatants of the two controls, the PLGA/ $\mathrm{Hb}^{\mathrm{PDA}} /\left(\mathrm{CeO}_{2}-\mathrm{NPs}\right)-\mathrm{NCs}$ (i), and PLGA/Hb $\mathrm{PDA} /\left(\mathrm{CeO}_{2}-\mathrm{NPs}\right) / \mathrm{PEG}-\mathrm{NCs}$ (ii). C) DIC images of blood cells incubated with the NCs. Insets show the NCs suspensions after overnight storage at $4{ }^{\circ} \mathrm{C}$. 

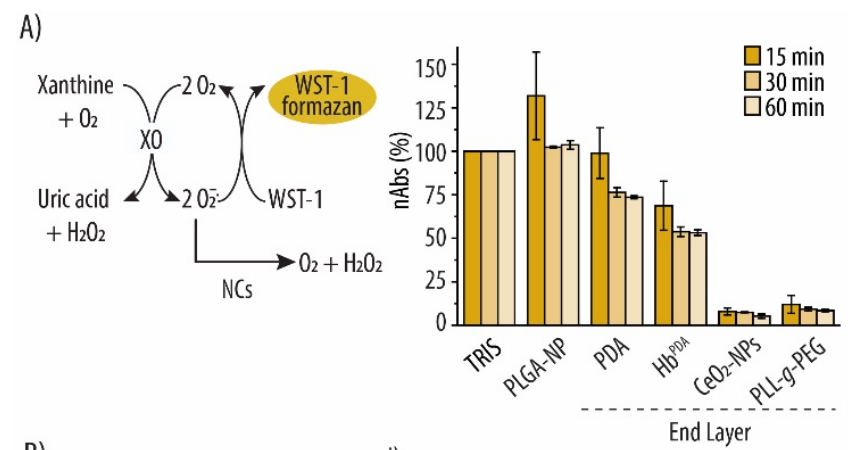

B)
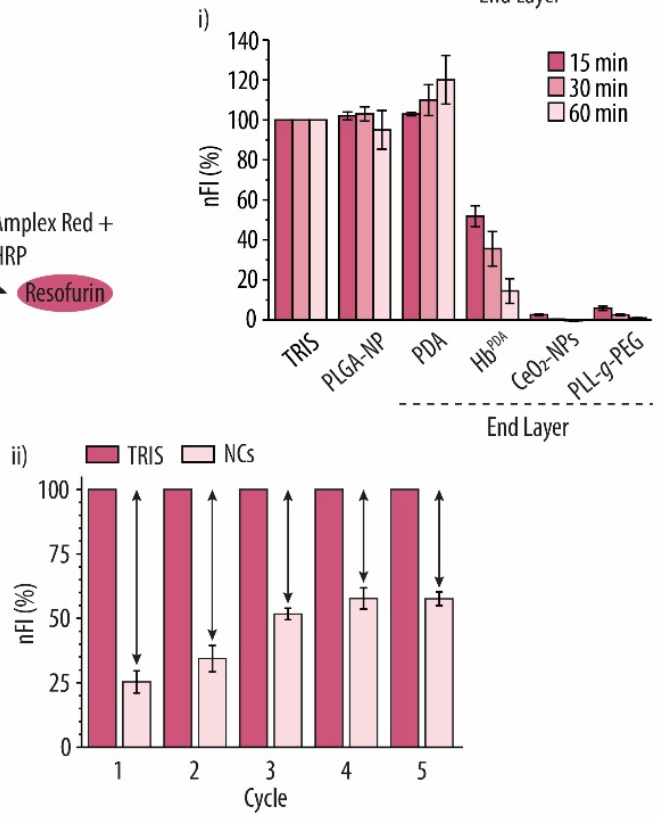

Figure 9. Catalytic activity of Hb-loaded NCs. A) SOD-like activity measured as the conversion of $\mathrm{O}_{2}{ }^{-}$into $\mathrm{H}_{2} \mathrm{O}_{2}$ using the WST-1 assay. nAbs readings measured after each deposition step for three time intervals. PLGA-NPs are coated with PDA followed by the deposition of $\mathrm{Hb}^{\mathrm{PDA}}, \mathrm{CeO}_{2}$ NPs, and PLL-g-PEG. B) Combined SOD-like and CAT-like activity evaluated by the Amplex Red assay. First, the NCs catalyze the decomposition of $\mathrm{O}_{2}{ }^{-}$into $\mathrm{H}_{2} \mathrm{O}_{2}$, followed by the subsequent decomposition of $\mathrm{H}_{2} \mathrm{O}_{2}$ into $\mathrm{O}_{2}$ and $\mathrm{H}_{2} \mathrm{O} . \mathrm{H}_{2} \mathrm{O}_{2}$ acts as a co-substrate for the conversion of the Amplex Red reagent into the fluorescent resorufin product in the presence of the enzyme HRP. nFI readings due to the fluorescent resorufin product after each deposition step of the NCs assembly for three different time intervals (i). Recyclability of the combined SOD- and CAT-like activity of the complete PLGA/ $\mathrm{Hb}^{\mathrm{PDA}} /\left(\mathrm{CeO}_{2}-\mathrm{NPs}\right) / \mathrm{PEG}-\mathrm{NCs}$ for five subsequent cycles (ii). 


\section{ASSOCIATED CONTENT}

\section{Supporting Information.}

Method section for the $\mathrm{Hb}$ extraction, synthesis of PLGA-NPs, BSA ${ }^{\mathrm{F}}$ and PLL-g-PEG; Detailed characterization methods for $\mathrm{Hb}^{\mathrm{PDA}}, \mathrm{CeO}_{2}-\mathrm{NPs}$, and LbL assembly of the NCs; Quantification of $\mathrm{CeO}_{2}-\mathrm{NPs}$ using UV-Vis and ICP-MS; saturation curves obtained by $\zeta$-potential measurements for the deposition of the subsequent layers during the NC assembly; Oxygen binding reversibility of $\mathrm{Hb}^{\text {PDA }}$ over time; Oxidative protection of $\mathrm{Hb}^{\text {PDA }}$ against $\mathrm{H}_{2} \mathrm{O}_{2}$.

\section{AUTHOR INFORMATION}

\section{Corresponding Author}

*E-mail: 1eri@dtu.dk

\section{Funding Sources}

This work has been supported by the Danish Council for Independent Research (Grant No. 611100298B). 


\section{REFERENCES}

(1) Jansman, M. M. T.; Hosta-Rigau, L. Recent and Prominent Examples of Nano- and Microarchitectures as Hemoglobin-Based Oxygen Carriers. Adv. Colloid Interface Sci. 2018, 260, 65-84. https://doi.org/10.1016/J.CIS.2018.08.006.

(2) Napolitano, L. M. Acute Traumatic Hemorrhage and Anemia. In Chemistry and Biochemistry of Oxygen Therapeutics: From Transfusion to Artificial Blood; Mozzarelli, A., Bettati, S., Eds.; Wiley Online Books; John Wiley \& Sons, Ltd, 2011; pp 79-106. https://doi.org/10.1002/9781119975427.ch6.

(3) Mirzakhani, H.; Nozari, A. Ischemia. In Chemistry and Biochemistry of Oxygen Therapeutics; Mozzarelli, A., Bettati, S., Eds.; Wiley Online Books; John Wiley \& Sons, Ltd, 2011; pp 145-158. https://doi.org/doi:10.1002/9781119975427.ch10.

(4) Sen Gupta, A. Bio-Inspired Nanomedicine Strategies for Artificial Blood Components. WIREs Nanomed. Nanobiotechnol. 2017, 9 (6), e1464. https://doi.org/10.1002/wnan.1464.

(5) Dwyre, D. M.; Fernando, L. P.; Holland, P. V. Hepatitis B, Hepatitis C and HIV Transfusion-Transmitted Infections in the 21st Century. Vox Sang. 2011, 100 (1), 92-98. https://doi.org/10.1111/j.1423-0410.2010.01426.x.

(6) Jia, Y.; Duan, L.; Li, J. Hemoglobin-Based Nanoarchitectonic Assemblies as Oxygen Carriers. Adv. Mater. 2016, 28 (6), 1312-1318. https://doi.org/10.1002/adma.201502581.

(7) Rother, R. P.; Bell, L.; Hillmen, P.; Gladwin, M. T. The Clinical Sequelae of Intravascular Hemolysis and Extracellular Plasma Hemoglobin. A Novel Mechanism of Human Disease. JAMA 2005, 293 (13), 1653-1662. https://doi.org/10.1001/jama.293.13.1653.

(8) Alayash, A. I. Blood Substitutes: Why Haven't We Been More Successful?; Elsevier Ltd, 2014; Vol. 32, pp 177-185. https://doi.org/10.1016/j.tibtech.2014.02.006.

(9) Natanson, C.; Kern, S. J.; Lurie, P.; Banks, S. M.; Wolfe, S. M. Cell-Free HemoglobinBased Blood Substitutes and Risk of Myocardial Infarction and Death. JAMA 2008, 299 
(19), 2304. https://doi.org/10.1001/jama.299.19.jrv80007.

(10) Awasthi, V.; Yadav, V. R.; Goins, B.; Phillips, W. T. Modulation of Oxidative Stability of Haemoglobin inside Liposome-Encapsulated Haemoglobin. J. Microencapsulation 2013, 30 (5), 471-478. https://doi.org/10.3109/02652048.2012.752535.

(11) Lu, M.; Zhao, C.; Wang, Q.; You, G.; Wang, Y.; Deng, H.; Chen, G.; Xia, S.; Zhao, J.; Wang, B.; Li, X.; Shao, L.; Wu, Y.; Zhao, L.; Zhou, H. Preparation, Characterization and in Vivo Investigation of Blood-Compatible Hemoglobin-Loaded Nanoparticles as Oxygen Carriers. Colloids Surf., B 2016, 139, 171-179.

(12) Wei, X.; Xiong, H.; He, S.; Wang, Y.; Zhou, D.; Jing, X.; Huang, Y. A Facile Way to Prepare Functionalized Dextran Nanogels for Conjugation of Hemoglobin. Colloids Surf., B 2017, 155, 440-448. https://doi.org/10.1016/J.COLSURFB.2017.04.047.

(13) Liu, X.; Jansman, M. M. T.; Hosta-Rigau, L. Haemoglobin-Loaded Metal Organic Framework-Based Nanoparticles Camouflaged with a Red Blood Cell Membrane as Potential Oxygen Delivery Systems. Biomater. Sci. 2020. https://doi.org/10.1039/D0BM01118E.

(14) Nagababu, E.; Rifkind, J. M. Heme Degradation by Reactive Oxygen Species. Antioxid. Redox Signaling 2004, 6 (6), 967-978. https://doi.org/10.1089/ars.2004.6.967.

(15) Staiculescu, M. C.; Foote, C.; Meininger, G. A.; Martinez-Lemus, L. A. The Role of Reactive Oxygen Species in Microvascular Remodeling. Int. J. Mol. Sci. 2014, 15 (12), 23792-23835. https://doi.org/10.3390/ijms151223792.

(16) Kuhn, V.; Diederich, L.; Keller, T. C. S.; Kramer, C. M.; Lückstädt, W.; Panknin, C.; Suvorava, T.; Isakson, B. E.; Kelm, M.; Cortese-Krott, M. M. Red Blood Cell Function and Dysfunction: Redox Regulation, Nitric Oxide Metabolism, Anemia. Antioxid. Redox Signaling 2017, 26 (13), 718-742. https://doi.org/10.1089/ars.2016.6954.

(17) Alagic, A.; Koprianiuk, A.; Kluger, R. Hemoglobin-Superoxide DismutaseChemical Linkages That Create a Dual-Function Protein. J. Am. Chem. Soc. 2005, 127 (22), 80368043. https://doi.org/10.1021/ja050339r. 
(18) Chen, B.; Jia, Y.; Zhao, J.; Li, H.; Dong, W.; Li, J. Assembled Hemoglobin and Catalase Nanotubes for the Treatment of Oxidative Stress. J. Phys. Chem. C 2013, 117 (38), 1975119758. https://doi.org/10.1021/jp407164q.

(19) D’Agnillo, F.; Chang, T. M. S. Polyhemoglobin-Superoxide Dismutase Catalase as a Blood Substitute with Antioxidant Properties. Nat. Biotechnol. 1998, 16 (7), 667-671. https://doi.org/10.1038/nbt0798-667.

(20) Bian, Y.; Rong, Z.; Chang, T. M. S. Polyhemoglobin-Superoxide Dismutase-CatalaseCarbonic Anhydrase: A Novel Biotechnology-Based Blood Substitute That Transports Both Oxygen and Carbon Dioxide and Also Acts as an Antioxidant. Artif. Cells, Blood Substit. And Biotechnol. 2011, 39 (3), 127-136. https://doi.org/10.3109/10731199.2011.581052.

(21) Liu, X.; Gao, Y.; Chandrawati, R.; Hosta-Rigau, L. Therapeutic Applications of Multifunctional Nanozymes. Nanoscale 2019, 11 (44), 21046-21060. https://doi.org/10.1039/c9nr06596b.

(22) Kang, T.; Kim, Y. G.; Kim, D.; Hyeon, T. Inorganic Nanoparticles with Enzyme-Mimetic Activities for Biomedical Applications. Coord. Chem. Rev. 2020, 403, 213092. https://doi.org/https://doi.org/10.1016/j.ccr.2019.213092.

(23) Jansman, M. M. T.; Hosta-Rigau, L. Cerium- and Iron-Oxide-Based Nanozymes in Tissue Engineering and Regenerative Medicine. Catalysts 2019, 9 (8), 691. https://doi.org/10.3390/cata19080691.

(24) Hosaka, H.; Haruki, R.; Yamada, K.; Böttcher, C.; Komatsu, T. Hemoglobin-Albumin Cluster Incorporating a Pt Nanoparticle: Artificial O2 Carrier with Antioxidant Activities. PLoS One 2014, 9 (10), e110541. https://doi.org/10.1371/journal.pone.0110541.

(25) Bertrand, N.; Leroux, J.-C. C. The Journey of a Drug-Carrier in the Body: An AnatomoPhysiological Perspective. J. Control. Release 2012, 161 (2), 152-163. https://doi.org/https://doi.org/10.1016/j.jconrel.2011.09.098.

(26) Suk, J. S.; Xu, Q.; Kim, N.; Hanes, J.; Ensign, L. M. PEGylation as a Strategy for Improving Nanoparticle-Based Drug and Gene Delivery. Adv. Drug Delivery Rev. 2016, 99 (Pt A), 28- 
51. https://doi.org/10.1016/j.addr.2015.09.012.

(27) York-Duran, M. J.; Godoy-Gallardo, M.; Jansman, M. M. T.; Hosta-Rigau, L. A DualComponent Carrier with Both Non-Enzymatic and Enzymatic Antioxidant Activity towards ROS Depletion. Biomater. Sci. 2019, 7 (11), 4813-4826. https://doi.org/10.1039/C9BM00913B.

(28) Ivanova, O. S.; Shekunova, T. O.; Ivanov, V. K.; Shcherbakov, A. B.; Popov, A. L.; Davydova, G. A.; Selezneva, I. I.; Kopitsa, G. P.; Tret'yakov, Y. D. One-Stage Synthesis of Ceria Colloid Solutions for Biomedical Use. Dokl. Chem. 2011, 437 (2), 103-106. https://doi.org/10.1134/S0012500811040070.

(29) Hosta-Rigau, L.; York-Duran, M. J.; Zhang, Y.; Goldie, K. N.; Städler, B. Confined Multiple Enzymatic (Cascade) Reactions within Poly(Dopamine)-Based Capsosomes. ACS Appl. Mater. Interfaces 2014, 6(15), 12771-12779. https://doi.org/10.1021/am502743z.

(30) Hosta-Rigau, L.; York-Duran, M. J.; Kang, T. S.; Städler, B. Extracellular Microreactor for the Depletion of Phenylalanine toward Phenylketonuria Treatment. Adv. Funct. Mater. 2015, 25 (25), 3860-3869. https://doi.org/10.1002/adfm.201404180.

(31) York-Duran, M. J.; Ek, P. K.; Godoy-Gallardo, M.; Hosta-Rigau, L. Shear Stress Regulated Uptake of Liposome-Decorated Microgels Coated with a Poly(Dopamine) Shell. Colloids Surf., B 2018, 171, 427-436. https://doi.org/10.1016/J.COLSURFB.2018.07.031.

(32) Liu, Y.; Ai, K.; Ji, X.; Askhatova, D.; Du, R.; Lu, L.; Shi, J. Comprehensive Insights into the Multi-Antioxidative Mechanisms of Melanin Nanoparticles and Their Application To Protect Brain from Injury in Ischemic Stroke. J. Am. Chem. Soc. 2017, 139 (2), 856-862. https://doi.org/10.1021/jacs.6b11013.

(33) Wang, Q.; Zhang, R.; Lu, M.; You, G.; Wang, Y.; Chen, G.; Zhao, C.; Wang, Z.; Song, X.; Wu, Y.; Zhao, L.; Zhou, H. Bioinspired Polydopamine-Coated Hemoglobin as Potential Oxygen Carrier with Antioxidant Properties. Biomacromolecules 2017, 18 (4), 1333-1341. https://doi.org/10.1002/adfm.201102737.

(34) Wang, Q.; Zhang, R.; You, G.; Hu, J.; Li, P.; Wang, Y.; Zhang, J.; Wu, Y.; Zhao, L.; Zhou, 
H. Influence of Polydopamine-Mediated Surface Modification on Oxygen-Release Capacity of Haemoglobin-Based Oxygen Carriers. Artif. Cells, Nanomedicine, Biotechnol. 2018, 46 (sup2), 484-492. https://doi.org/10.1080/21691401.2018.1459636.

(35) Baidukova, O.; Wang, Q.; Chaiwaree, S.; Freyer, D.; Prapan, A.; Georgieva, R.; Zhao, L.; Bäumler, H. Antioxidative Protection of Haemoglobin Microparticles (HbMPs) by PolyDopamine. Artif. Cells, Nanomedicine, Biotechnol. 2018, 46 (sup3), S693-S701. https://doi.org/10.1080/21691401.2018.1505748.

(36) Liu, X.; Jansman, M. M. T.; Thulstrup, P. W.; Mendes, A. C.; Chronakis, I. S.; Hosta-Rigau, L. Low-Fouling Electrosprayed Hemoglobin Nanoparticles with Antioxidant Protection as Promising Oxygen Carriers. Macromol. Biosci. 2020, $20 \quad$ (2), 1900293. https://doi.org/10.1002/mabi.201900293.

(37) Hennessey, J. P.; Johnson, W. C. Information Content in the Circular Dichroism of Proteins. Biochemistry 1981, 20 (5), 1085-1094. https://doi.org/10.1021/bi00508a007.

(38) Jia, Y.; Alayash, A. I. Effects of Cross-Linking and Zero-Link Polymerization on Oxygen Transport and Redox Chemistry of Bovine Hemoglobin. Biochim. Biophys. Acta, - Proteins Proteomics 2009, 1794 (8), 1234-1242. https://doi.org/10.1016/j.bbapap.2009.04.008.

(39) Lai, Y. T.; Sato, M.; Ohta, S.; Akamatsu, K.; Nakao, S. ichi; Sakai, Y.; Ito, T. Preparation of Uniform-Sized Hemoglobin-Albumin Microspheres as Oxygen Carriers by Shirasu Porous Glass Membrane Emulsification Technique. Colloids Surf., B 2015, 127, 1-7. https://doi.org/10.1016/j.colsurfb.2015.01.018.

(40) Storz, J. F. A Study in Scarlet. In Hemoglobin: Insights into protein structure, function, and evolution; Oxford University Press: New York, NY, 2019; pp 20-25. https://doi.org/10.1093/oso/9780198810681.003.0002.

(41) Celardo, I.; Pedersen, J. Z.; Traversa, E.; Ghibelli, L. Pharmacological Potential of Cerium Oxide Nanoparticles. Nanoscale 2011, $3 \quad$ (4), 1411-1420. https://doi.org/10.1039/c0nr00875c.

(42) Zhang, F.; Chan, S.-W.; Spanier, J. E.; Apak, E.; Jin, Q.; Robinson, R. D.; Herman, I. P. 
Cerium Oxide Nanoparticles: Size-Selective Formation and Structure Analysis. Appl. Phys. Lett. 2002, 80 (1), 127-129. https://doi.org/10.1063/1.1430502.

(43) Arıca, M. Y.; Öktem, H. A.; Öktem, Z.; Tuncel, S. A. Immobilization of Catalase in Poly(Isopropylacrylamide-Co-Hydroxyethylmethacrylate) Thermally Reversible Hydrogels. Polym. Int. 1999, 48 (9), 879-884. https://doi.org/10.1002/(SICI)10970126(199909)48:9<879::AID-PI237>3.0.CO;2-N.

(44) Peng, S.; Liu, J.; Qin, Y.; Wang, H.; Cao, B.; Lu, L.; Yu, X. Metal-Organic Framework Encapsulating Hemoglobin as a High-Stable and Long-Circulating Oxygen Carriers to Treat Hemorrhagic Shock. ACS Appl. Mater. Interfaces 2019, 11 (39), 35604-35612. https://doi.org/10.1021/acsami.9b15037.

(45) Rudolph, A. S.; Klipper, R. W.; Goins, B.; Phillips, W. T. In Vivo Biodistribution of a Radiolabeled Blood Substitute:99mTc-Labeled Liposome-Encapsulated Hemoglobin in an Anesthetized Rabbit. Proc. Natl. Acad. Sci. U. S. A. 1991, 88 (23), 10976-10980. https://doi.org/10.1073/pnas.88.23.10976.

(46) Taguchi, K.; Watanabe, H. A Fourteen-Day Observation and Pharmacokinetic Evaluation after a Massive Intravenous Infusion of Hemoglobin-Vesicles (Artificial Oxygen Carriers) in Cynomolgus Monkeys. J. Drug Metab. Toxicol. 2012, 3 (4), 128. https://doi.org/10.4172/2157-7609.1000128.

(47) Godoy-Gallardo, M.; Labay, C.; Hosta-Rigau, L. Tyrosinase-Loaded Multicompartment Microreactor toward Melanoma Depletion. ACS Appl. Mater. Interfaces 2019, 11 (6), 5862 5876. https://doi.org/10.1039/c5qi00240k.

(48) Godoy-Gallardo, M.; Labay, C.; Jansman, M. M. T.; Ek, P. K.; Hosta-Rigau, L. Intracellular Microreactors as Artificial Organelles to Conduct Multiple Enzymatic Reactions Simultaneously. Adv. Healthc. Mater. 2017, $6 \quad$ (4), 1601190. https://doi.org/10.1002/adhm.201601190.

(49) Teo, B. M. B. M.; Hosta-Rigau, L.; Lynge, M. E. M. E.; Städler, B. Liposome-Containing Polymer Films and Colloidal Assemblies towards Biomedical Applications. Nanoscale 
2014, 6 (12), 6426-6433. https://doi.org/10.1039/c4nr00459k.

(50) Jin, A.; Wang, Y.; Lin, K.; Jiang, L. Nanoparticles Modified by Polydopamine: Working as "Drug" Carriers. Bioact. Mater. 2020, 5 (3), 522-541. https://doi.org/https://doi.org/10.1016/j.bioactmat.2020.04.003.

(51) Lévy, R.; Thanh, N. T. K.; Doty, R. C.; Hussain, I.; Nichols, R. J.; Schiffrin, D. J.; Brust, M.; Fernig, D. G. Rational and Combinatorial Design of Peptide Capping Ligands for Gold Nanoparticles. J. Am. Chem. Soc. 2004, 126 (32), 10076-10084. https://doi.org/10.1021/ja0487269.

(52) Spencer, N. D.; Hubbell, J. A.; Michel, R.; Hofer, R.; Elbert, D. L.; Huang, N.-P.; Voros, J.; Rossi, A.; Textor, M. Poly(L-Lysine)-g-Poly(Ethylene Glycol) Layers on Metal Oxide Surfaces: Surface-Analytical Characterization and Resistance to Serum and Fibrinogen Adsorption. Langmuir 2002, 17 (2), 489-498. https://doi.org/10.1021/la000736+.

(53) Patil, S.; Sandberg, A.; Heckert, E.; Self, W.; Seal, S. Protein Adsorption and Cellular Uptake of Cerium Oxide Nanoparticles as a Function of Zeta Potential. Biomaterials 2007, 28 (31), 4600-4607. https://doi.org/https://doi.org/10.1016/j.biomaterials.2007.07.029.

(54) Zhang, S.; Moustafa, Y.; Huo, Q. Different Interaction Modes of Biomolecules with CitrateCapped Gold Nanoparticles. ACS Appl. Mater. Interfaces 2014, 6 (23), 21184-21192. https://doi.org/10.1021/am506112u.

(55) Liu, H.; Qu, X.; Tan, H.; Song, J.; Lei, M.; Kim, E.; Payne, G. F.; Liu, C. Role of Polydopamine's Redox-Activity on Its pro-Oxidant, Radical-Scavenging, and Antimicrobial Activities. Acta Biomater. 2019, 88, 181-196. https://doi.org/https://doi.org/10.1016/j.actbio.2019.02.032. 
TABLE OF CONTENTS GRAPHIC
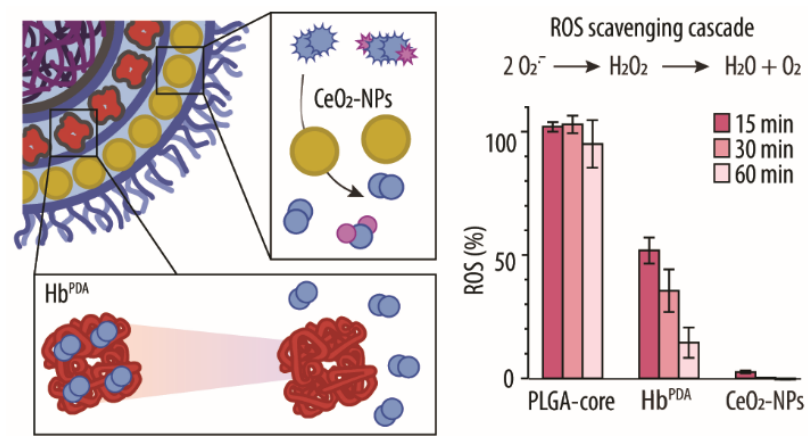